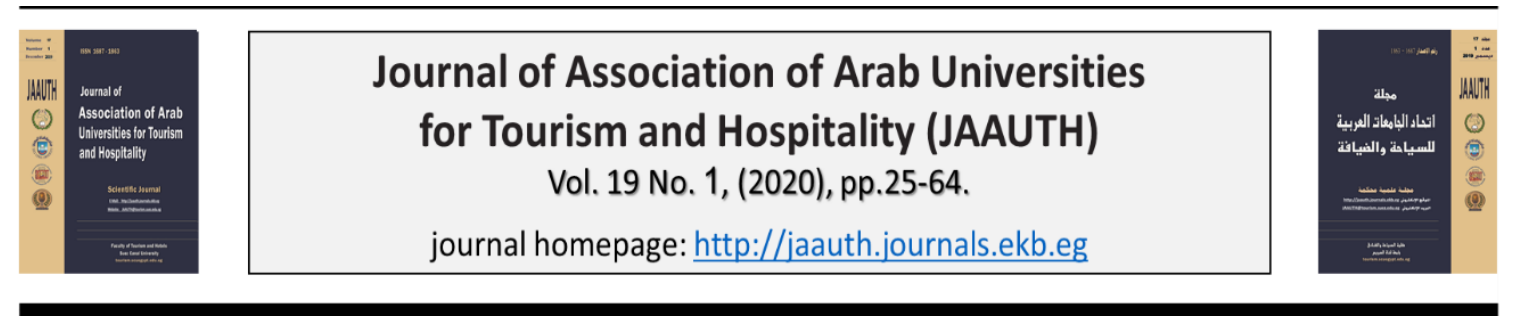

\title{
Praying Beads and Praying Ropes in Coptic Art in the Context of Coptic Heritage
}

\section{Sara el-Sayed Kitat ${ }^{1}$}

Zeinab Hanafy Hassan ${ }^{2}$

${ }^{\mathbf{1}}$ Associate professor in Tour Guiding Department, Faculty of Tourism and Hotels, Alexandria University

${ }^{2}$ Assistant Researcher, Center for Coptic Studies, Bibliotheca Alexandrina

\begin{tabular}{|c|c|}
\hline ARTICLE INFO & Abstract \\
\hline $\begin{array}{l}\text { Keywords: } \\
\text { Praying; Beads; } \\
\text { Ropes; Saint; Heritage. } \\
\\
\text { (JAAUTH) } \\
\text { Vol. 19, No. 1, } \\
\text { (2020), } \\
\text { PP. 25-64. }\end{array}$ & $\begin{array}{l}\text { In Christianity, praying beads and praying ropes are used by } \\
\text { pious people to keep counting their prayers. By the third } \\
\text { century AD, these beads were mentioned in Egypt through the } \\
\text { writings of the first Deserts Fathers. Thus, they were used in } \\
\text { Egypt even before using the Dominican Rosary in Europe in } \\
\text { the thirteenth century AD. The invention of praying ropes was } \\
\text { attributed to St. Anthony who tied a leather rope every time he } \\
\text { started praying "Kyrie Elesion". In Coptic art, praying beads } \\
\text { and praying ropes are represented either in the right hand or } \\
\text { the left hand of prominent monastic characters. They were } \\
\text { accompanied with the cross, the staff, and with the adoration } \\
\text { gesture made by one or both hands. Icons from the churches of } \\
\text { Old Cairo, monasteries of Wadi El-Natrun, and the } \\
\text { monasteries of the Red Sea and Upper Egypt reveal the shape } \\
\text { of praying beads and praying ropes. These hand objects are } \\
\text { still used in modern monastic life forming a tangible element } \\
\text { of the Coptic heritage of Egypt. }\end{array}$ \\
\hline
\end{tabular}

\section{Introduction}

The word "bead" is inspired from the Anglo-Saxon word "Bede", which means "prayer". It is generally defined by Blackman to be "a string of knots or beads". Praying beads were known in the ancient civilizations. They apparently appeared as early as the Assyrian empire. This object helped pious people since ancient times to count their prayers by counting the small pebbles dropped into their labs. By this way, praying became easier and was recited with more concentration. Five hundred years before Christianity, tying knots in strings or cords for religious purposes was a familiar tradition. ${ }^{3}$

In Christianity, "praying beads" or "praying ropes" are used by religious people and are accompanied with certain bodily, vocal and mental actions during their prayers. In other words, the lips, fingers, and definitely the minds of the Christian worshippers are involved during using their praying beads. ${ }^{4}$ Thus, many religionists enhance using such beads which enable its bearer to keep track of a repetitive prayer leading to a clear mind and a relaxing phycological state. ${ }^{5}$ 
Recent studies threw the light on the European Catholic Rosary which is attributed to St. Dominic (1172-1221AD) in the thirteenth century and considered it the origin of such hand object in the Christian world. However, these studies did not mention the Coptic praying beads and praying ropes in Egypt which were invented centuries earlier. Hence, this paper aims to pursue the origin of Coptic praying beads and ropes and their artistic connotation in Coptic art. The study analyzes the monastic figures which were depicted carrying praying beads and ropes. Coptic icons represent certain hand gestures being performed by the carrier of such hand objects. Thus, the association between the praying beads and ropes and these bodily postures and gestures is investigated in this research. Being a contemporary part of the monastic life in Egypt nowadays, this paper throws the light on the Coptic praying beads and ropes as a remarkable part of Egyptian tangible Coptic heritage.

\section{Coptic Praying Beads and Ropes, Origin and Development}

Catholic praying beads are known as "rosary"6; a word that is driven from the Latin word "rosarius" which means "garden", "bouquets" or "garden of roses". They consist of a string, which is known as paternosters, ${ }^{7}$ of one hundred and fifty beads; divided into groups of ten. ${ }^{8}$ The rosary can include fifty-nine beads, six large and fifty-three small; and divided into five groups of ten small beads and one large bead each, plus a pendant of one large bead and three small ones that terminates with a cross. ${ }^{9}$ Certain praying was repetitively recited while using these beads such as; "Hail Mary" and the "Our Father". 10 The repetitive recitation of 150 "Our Father" might have been a substitute for reciting the Psalms of David where "Our Father" was divided into groups of three fifties. These recitations were mainly used by illiterate people, mainly monks, who were not capable of reciting the Psalms. ${ }^{11}$

Marian Devotion suggests another recitation by repeating "Hail Mary" fifty, hundred or 150 times recited on a Rosary. ${ }^{12}$ The prayers used are fifteen "decades" tens of "Hail Mary", each decade preceded by an "our father" and concluded by a "glory be" the fifteen recited mysteries or topics of meditation are grouped in series of five which are usually prayed separately: The Joyful Mysteries, The sorrowful Mysteries and the Glorious Mysteries. ${ }^{13}$

According to some references, the Rosary was developed by St. Dominic (1172$1221 \mathrm{AD})$ in the thirteenth century. It was given to him by Virgin Mary who appeared to him when he was praying for a weapon to use against those who opposed Christianity. ${ }^{14}$ Prayer activity was attested in medieval European monasteries and enabled illiterate Christians in counting their recitations. Thus, the Rosary is used by the liturgical churches, the Eastern Orthodox, the Anglicans and the Catholics. Concerning the nonliturgical Christian churches, they do not use Rosary in the praying. ${ }^{15}$

Group of scholars believes that the Rosary was introduced to Europe during the time of Crusaders being inspired from the praying beads used by the Muslims. However, this opinion is a topic of debate. ${ }^{16}$ Unlike the Rosary which was attributed to St. Dominic in the thirteenth century, the Coptic praying beads and praying ropes appeared centuries earlier. This is because of being important hand objects that appeared by the beginning of monasticism in Egypt. Thus, Egypt seems to be the cradle of inventing praying beads and praying ropes and spread after that in the Christian world. 
By the third century, these beads were firstly mentioned in the writings of the first deserts fathers and mothers who isolated themselves in the Egyptian deserts. They began to use pebbles placed in their pockets and drop them one by one during recitation in order to count their prayers. Later on, these pebbles were strung on a cord and carried. ${ }^{17}$ It is known that the Egyptian Abbot Paul (died in 341 AD) recited threehundred prayers every day. This saint preserved kind of pebbles in his cloak dropping them one by one to count on counting his recitations. ${ }^{18}$ It was said that St. Paul collected three hundred pebbles and sat on a side as each prayer finished. ${ }^{19}$

Concerning the praying ropes, they were also firstly invented of the early Egyptian monks. Scholars believe the earliest monks in Egypt must have had a way for counting their prayers. ${ }^{20}$ The invention of such ropes was attributed to St. Anthony, the father of the orthodox monasticism. The great saint tied a leather rope every time he started praying "Kyrie Elesion" ${ }^{21}$ meaning (Lord have mercy), but the Satan dismantled the knots. Then, St. Anthony devised a way to untie the knots with seven warps and crossing the rope and each knot held within it the sign of the cross. By this way, the devil could not tie the rope as he was incapable of bearing the sign of the cross. ${ }^{22}$

According to Eastern Orthodox Christianity, the praying rope was named

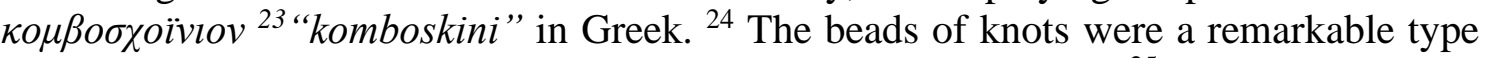
of praying ropes which was used during crucial ceremonial rituals. ${ }^{25}$ The number of the knots varied from one monastery to another. ${ }^{26}$ The knots were usually thirty-three, referring to the thirty-three years of the Christ's life. ${ }^{27}$ The knots were divided by four double knots in the corners. By this way, praying ropes housed the same number of a short rosary with thirty-two beads. ${ }^{28}$ Other examples of praying ropes house fifty or one hundred knots. ${ }^{29}$

The praying ropes are usually made of wool; to stand for the flock of the Christ and it is also black reflecting the bearer's sins. Instead of a crucifix, they added a knotted cross ${ }^{30}$. The komboskini is part of the monastic costume of the great skeme, namely the Megaloskema ${ }^{31}$ and officially given at the profession, together with the mandyas (pallium). Both praying beads and praying ropes are used till now in the modern Orthodox churches in Egypt. Such beads are considered highly ceremonial. ${ }^{32}$ Gaster stated that these knots formed the primitive shape of praying beads. In other words, the shape of praying beads developed mainly from the strings of mnemonic knots. ${ }^{33}$

Following the tradition of St. Anthony, the invention of praying beads was necessary to enable the Copts, particularly the monks, to keep counting the phrase "Kyrie Elesion". 34 This phrase is the Greek translation for "Lord have mercy". Both St. Jerome (C. 342240 AD) and St. Gregory of Nazianus (329-389 AD) stated that this phrase was introduced by the apostles to the church. This petition was used in the Psalms as well as the Pharisee and the Publican (Luke 18:13) and in various parts of the Gospels. The aim of this petition is asking for the mercy of the Christ. ${ }^{35}$

In addition to "Kyrie Elision", Orthodox most frequently recited "the Prayer of the Heart" or "the Jesus Prayer" which says; "Lord, Jesus Christ, have mercy on me, a sinner". 36 This phrase is repeated in penitent mediation forming part of Pauline "praying without ceasing" which is mentioned in the New Testament (1 Thess. 5:17). Primitive recitation of this prayer is mentioned in (John 16: 23) forming one or two 
words recited unceasingly. Furthermore, Jesus Prayer is derived from lamentations mentioned in Psalms, namely "the Prayer of the Publican" (Luke 18:13) and "the Prayer of the Blind Man" (Luke 18: 38). ${ }^{37}$

Jesus Prayer became part of the Egyptian monasticism as early as the fourth century since it was firstly recited by St.Macarius the Great (Macarius the Egyptian). This saint mentioned the recitation of small phrases as an unceasing supplication of penance. ${ }^{38}$ For instance, the phrase "Our Lord Jesus, have mercy on me" was mentioned in the Virtues of St.Macarius (Virtues 41). ${ }^{39}$ In Apophthegmata Partum of Macarius the Great, a shorter phrase was mentioned "Lord, help!"40

Copts repeat the prayers whether in Arabic or Coptic, with a short Coptic prayer at the end. Sometimes, the Copts resort to what is presumably a more primitive way of counting as they count the prayers on their fingers. Coptic prayer beads hosed either forty-one or sixty-one beads. ${ }^{41}$ The prayer holds the robe of beads in his left hand, leaving his right hand free to make the sign of the cross. ${ }^{42}$

\section{The Iconography of Praying Beads and Praying Ropes in Coptic Art}

The iconography of praying beads was not attested before Christianity. However, praying beads might have inspired their shape from similar pendants of beads in Greek art. Among the frescos of the Greek Thira island (modern Santorini), the most ancient iconography of a chain of beads is found on a fresco painting which is recently excavated in Akrotiri of Thira. This fresco dates back to 1600 B.C. and covers the north wall of the adyton of the Minoan goddess. It shows the seated wounded goddess, ${ }^{43}$ in the middle flanked by two woman presenting gifts to her. ${ }^{44}$ The goddess is wounded in her feet from which a crocus sprout revealing her divine nature. ${ }^{45}$ The female figure on the left holds in her left hand a red colored bead which is terminated at the top with a pendant of beads (fig.1). Marinatos defined this bead to be a necklace apparently presented to the goddess. ${ }^{46}$

According to Gaster, these beads placed in strings were similar in shape with the Christian praying beads. Such pendants of beads were offered to deities in their shrines in pagan cultures. ${ }^{47}$ However, this hypothesis is a topic of debate as the depicted pendant of beads was not used for reciting prayers. Furthermore, Coptic praying beads are historically attested in the Christian world even before the Rosary of the Western Churches. Thus, the iconography of this hand object would be firstly attested in Egypt.

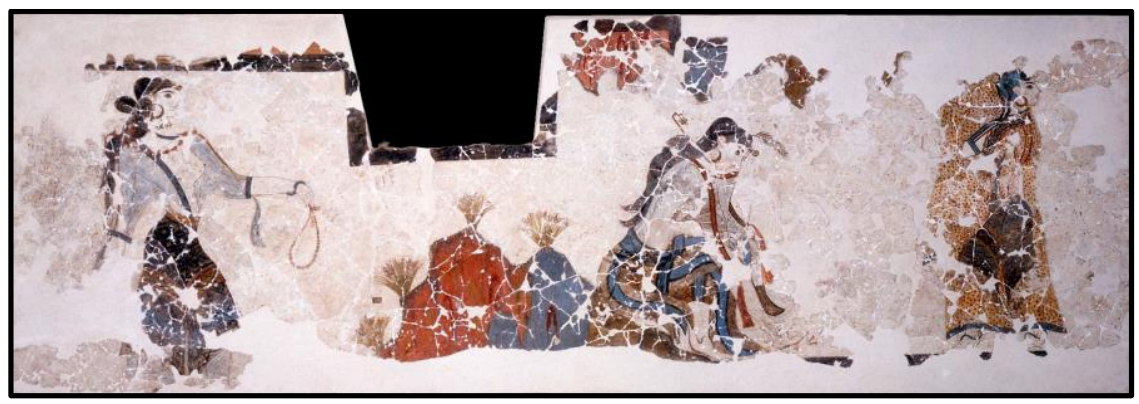

Fig.1. Fresco painting showing three female figures, the woman on the left is carrying a red colored bed in her hand, 1600 B.C., discovered in Akrotiri of Thira, modern Santorini, preserved in the National Archaeological Museum, Greece After: Marinatos, Akrotiri, 122, 123. 
St. Paul the Hermit ${ }^{48}$ is one of the remarkable characters who was repetitively depicted with praying beads in Coptic Icons. Concerning this well-preserved icon, it dates back to the seventeenth- eighteenth centuries AD and is preserved in the Coptic Museum (nr. 3431). The icon shows St. Paul $^{49}$ raising his both hands in adoration. The saint is depicted wearing a humble dress made of plaited palm leaves and tied from his waist with a brown belt; a liturgical girdle known as zonarion. Black prayer beads adorned with Greek cross are portrayed being suspended from his belt beneath his left hand, a crow with a bread loaf in his bead is seen beside the head of the saint (fig.2).

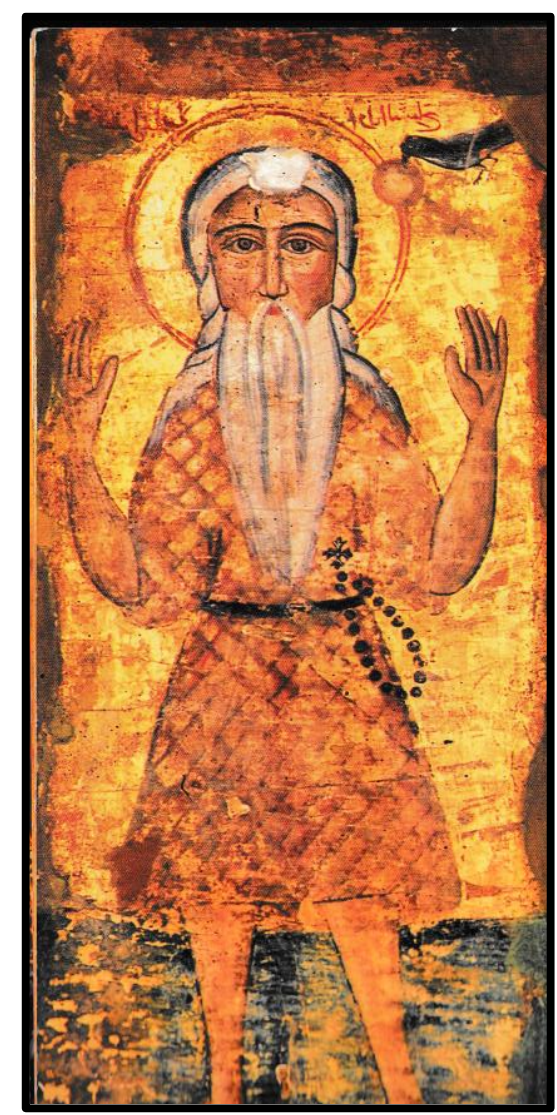

Fig.2. Icon of St. Paul with chain of praying beads suspending from the zonarion, seventeenth -eighteenth century AD, Coptic Museum (no. 3431), Cairo After: Selections from the Egyptian heritage: Icons of the Coptic Museum, 11

Almost an identical iconography for St. Paul is found on the left wing of a fragmentary triptych preserved now in the Coptic Museum of Egypt (nr. 3431). The piece was discovered in the church of the martyr Plitha (or Colluthos?) and depicts the full-length portraiture of St. Paul. Black praying beads are depicted being attached to the zonarion around his brown sack-garment. The saint is raising his both hands in the gesture of praying. Based on its artistic style, this piece is attributed to Ibrahim el-Nasikh from the eighteenth-century AD (fig. 3). 


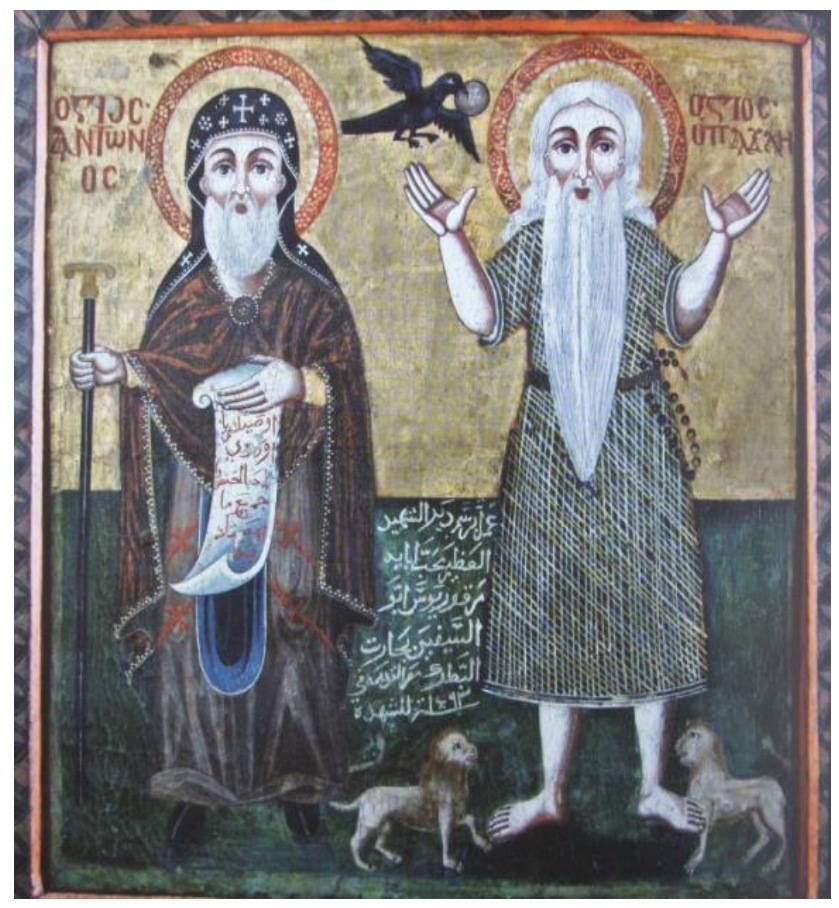

Fig.3. Icon depicting the visit of St. Anthony (left) to St. Paul (right), discovered in the Monastery of Macarius (Abu Sayfayn) in Old Cairo, 1777 AD, Coptic Museum of Cairo (no. 34180)

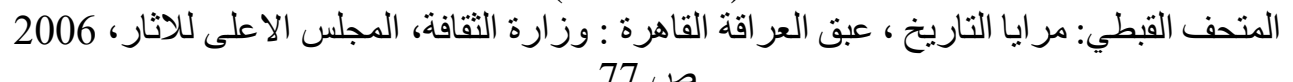

In the Church of St. Shenouti ${ }^{51}$ in Old Cairo, there is a remarkable Coptic triptych that depicts Crowned Virgin Mary and Jesus Christ flanked by both St. Anthony (right) ${ }^{52}$ and St. Paul (left). ${ }^{53}$ St. Anthony holds a tau-staff in his right hand and small black praying beads in his left one. He wears a black kalansuwa adorned with shapes of white crosses, a red mandyas, a blue tunic and a red epitrachelion with shapes of golden crosses. Concerning St. Paul, he holds a chain of black praying beads in his right hand which is raised with his left one making the adoration gesture. The praying beads of St. Paul seems to have more pebbles than that of St. Anthony. A small Latin cross adorns the praying beads of St. Paul, which is placed between his thumb and his index finger. The saint is depicted wearing a humble dress made of plaited palm leaves and tied from his waist with a zonarion. The figure of both saints is identified with their names written in Arabic. As for Virgin Mary and Jesus the Child, their Coptic names are written beside their heads (fig.4). 


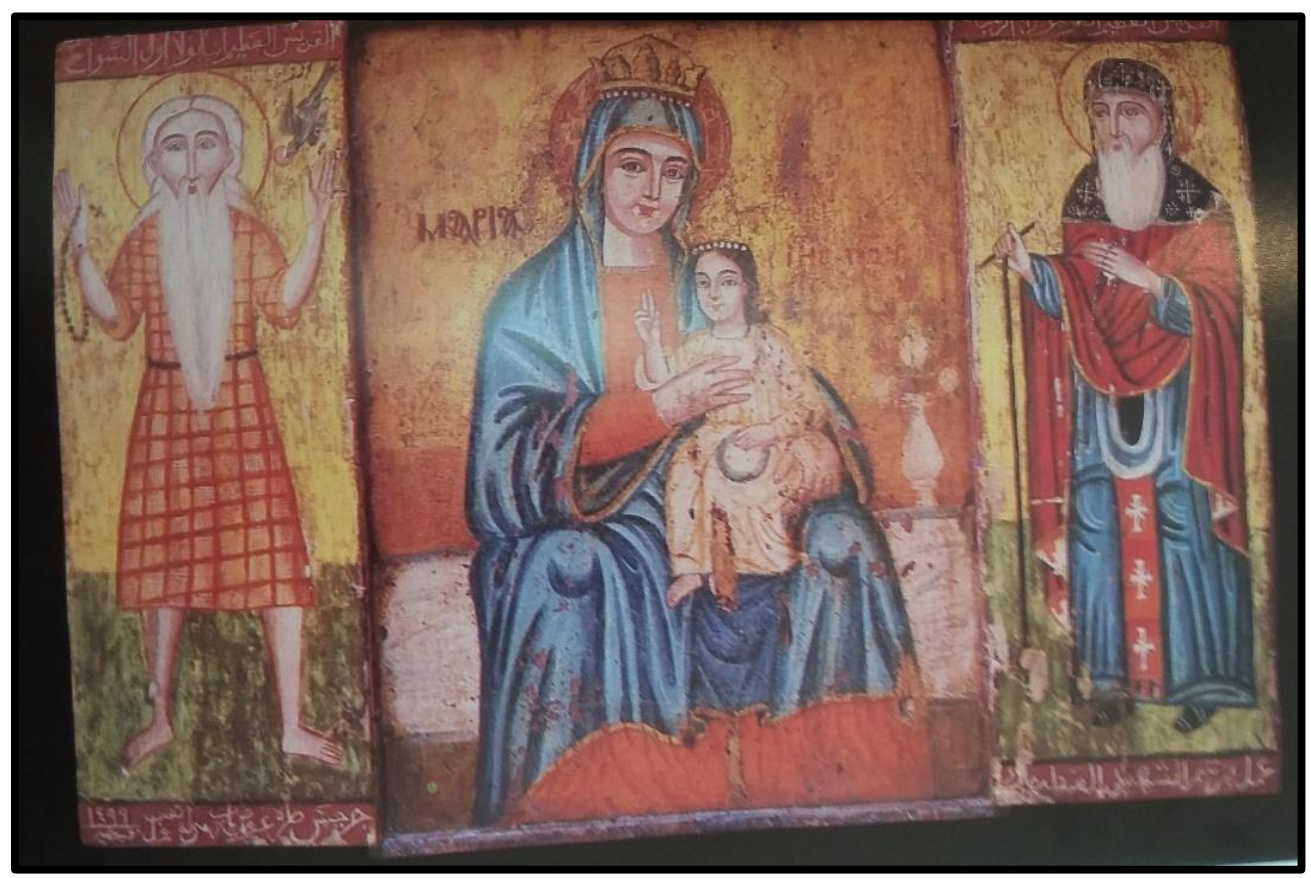

Fig.4. Coptic triptych that depicts Virgin Mary and Jesus Christ flanked by St. Anthony and St. Paul Church of St. Shenouti in Old Cairo

After: Attalah, Coptic Icons, Les Icônes Coptes, 123

Another remarkable icon is found in the church of St. Cyrus and St. John in Old Cairo ${ }^{54}$. Van Morsel identified this icon to be brought from the church of Shebin ElKom near Tanta. Now, it is persevered in the Coptic Museum of Cairo (nr. 3363) and dates back to $1844 \mathrm{AD}$, mainly related to Anastasia's style. The painter's works are remarked with using luminous colors. The upper part of the Icon represents the crowned Virgin Mary and Jesus the Child (crowned Hodegetria); the favorite theme of Anastasia. ${ }^{55}$ The lower part depicts two soldier saints, apparently St. George and St. Macarius (Abu Seifien), flanked by both St. Paul (left) and St. Anthony (right). St. Paul is depicted wearing a red sack- cloth. As for St. Anthony, he wears a black kalansuwa adorned with shapes of white crosses, a creamy colored tunic and a pink mandyas. The two saints are depicted and holding black praying beads with their outstretched left hands and holding the Latin cross with their right ones. The two chains end with the shape of the cross topped by a tassel. (fig.5). 


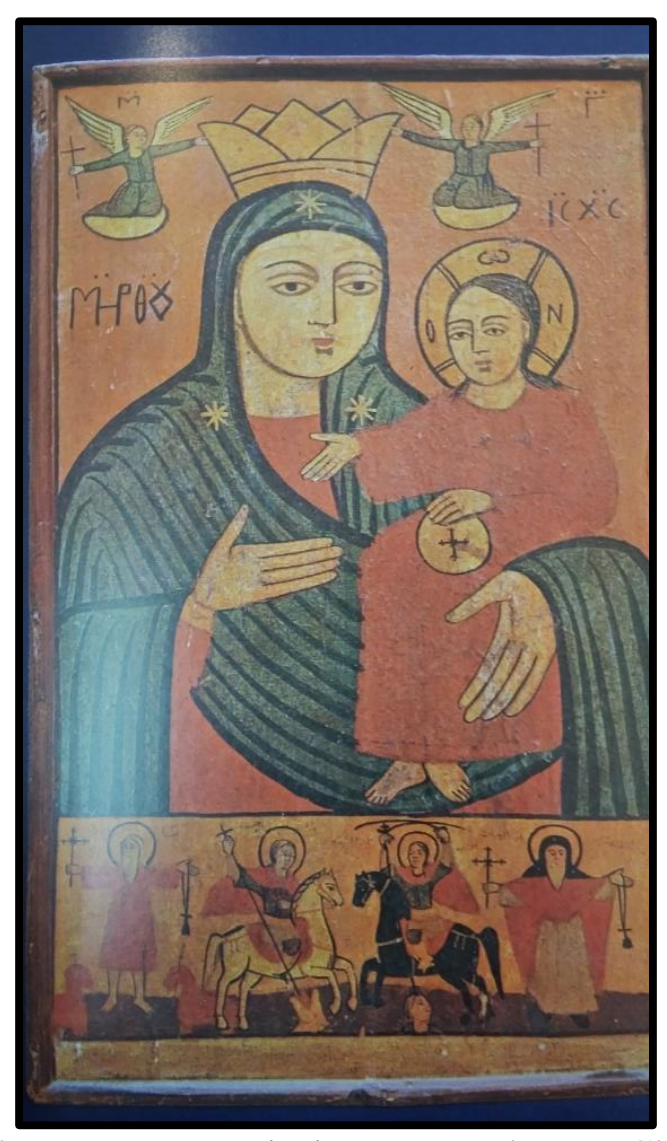

Fig.5. Coptic icon that represents Virgin Mary and Jesus Christ (upper part), St. Anthony (lower part to the right) and St. Paul (lower part to the left) holding praying beads, Coptic Museum of Cairo (nr. 3363), 1844 AD

After; Attalah, Coptic Icons,Les Icônes Coptes, 25

There is almost an identical icon now preserved in the Coptic Museum of Cairo (nr. 3365). Like the previous piece, this icon follows the Anastasia's artistic style and dates back to 1844 AD. The upper part of the icon represents the holy Virgin Mary being crowned and Jesus the Child (crowned Hodegetria). The lower part of the icon represents four characters, namely two soldier saints and two standing saints arranged from left to right as follows; St. George, another soldier saint, St. Paul the Hermit, and St. Anthony. St. Paul is depicted wearing a red sack- cloth. As for St. Anthony, he wears a black kalansuwa adorned with shapes of white crosses, green tunic, a red epitrachelion and a pink mandyas. ${ }^{56}$ Black praying beads ending with the shape of the cross and topped by a tassel are found in their left hands and the Latin cross in their right ones (fig.6). 


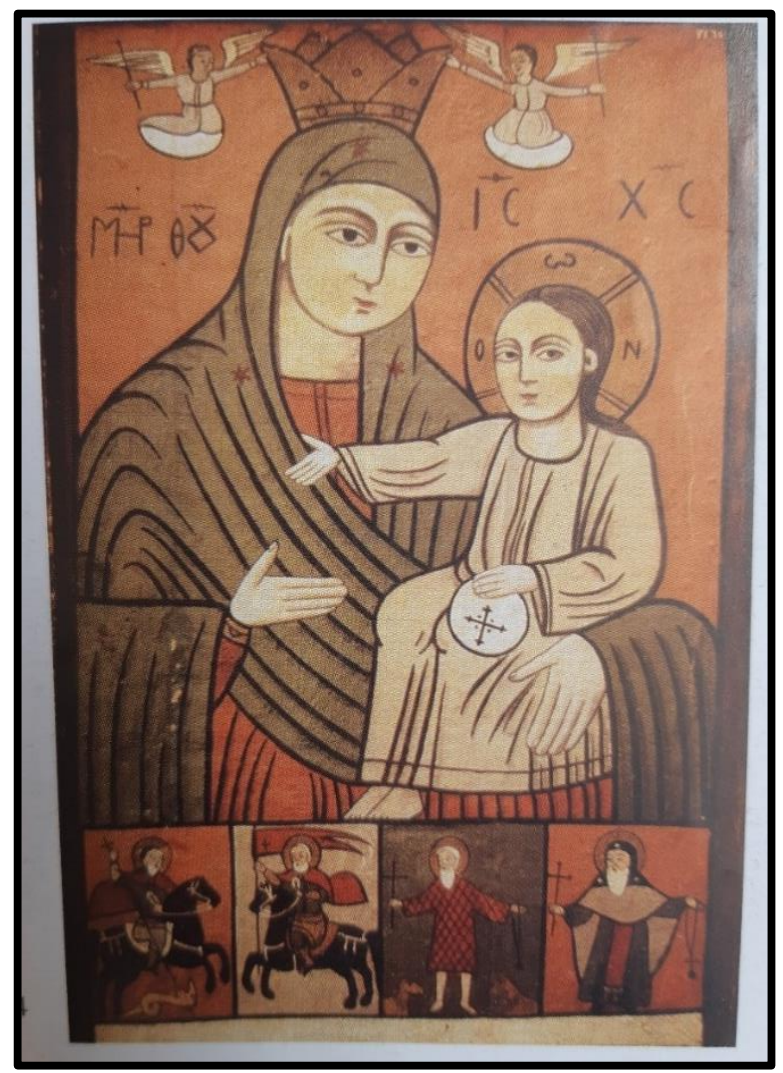

Fig.6. Icon depicting St. Paul and St. Anthony (lower part) holding black praying beads, Coptic Museum of Cairo (nr. 3365), 1844 AD After: Van Moorsel, the Icons, 64, pl. G2.

Another example represents both St. Abraham (left) and St. George of Scetis (right) ${ }^{57}$ carrying praying beads. St. Abraham is depicted holding the tau-staff terminated with knobs in his right hand. In his left hand, he holds a chain of black praying beads which end with a cross and a tassel. The saint is dressed in a black kalansuwa, a pink tunic, a green mandyas. As for St. George, a Latin cross is in his right hand and black praying beads in his left one. He wears a red tunic and a pink mandyas. This piece is now preserved in the Coptic Museum in Cairo (nr. 3445) and follows the Anastasia's artistic style of the nineteenth century $\mathrm{AD}$ (fig.7). ${ }^{58}$ 


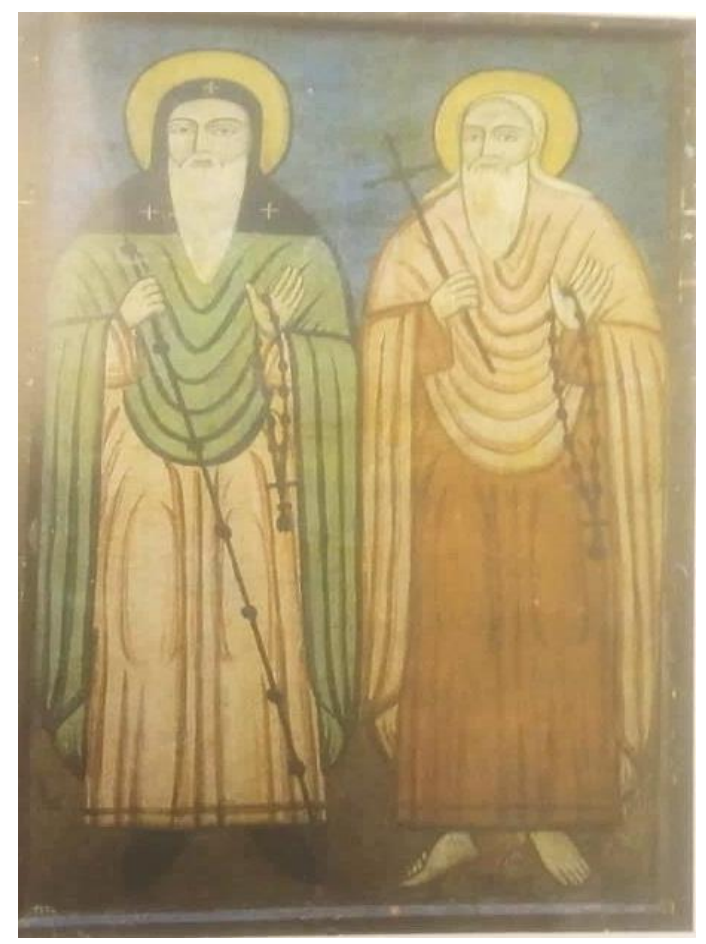

Fig. 7. Icon depicting St. Abraham (left) and St. George of Scetis (right) carrying praying beads, Coptic Museum in Cairo (nr. 3445), eighteenth-century AD

After: Hondelink, Hans, Coptic Art and Culture, Cairo Shouhdy, The Netherlands Institute for Archaeology and Arabic Studies in Cairo,1990, pl.4.5

A remarkable icon of Markus al-Antuni ${ }^{59}$ depicts the saint holding a chain of prayer beads in his hand. This icon was executed by Ibrahim el- Nasikh and dates back to the eighteenth century AD, mainly to 1768-1769 AD. This icon is found in the Monastery of St. Antony. ${ }^{60}$ Markus al-Antuni is depicted holding a long tau-stuff in his right hand and white praying beads in his left hand. The icon represents a striking iconography of this object which is depicted being hung on the thumb of the saint and ends with the shape of the Greek cross. The saint wears the black kalansuwa bearing the shape of crosses, red tunic, and a blue mandyas (fig.8). 


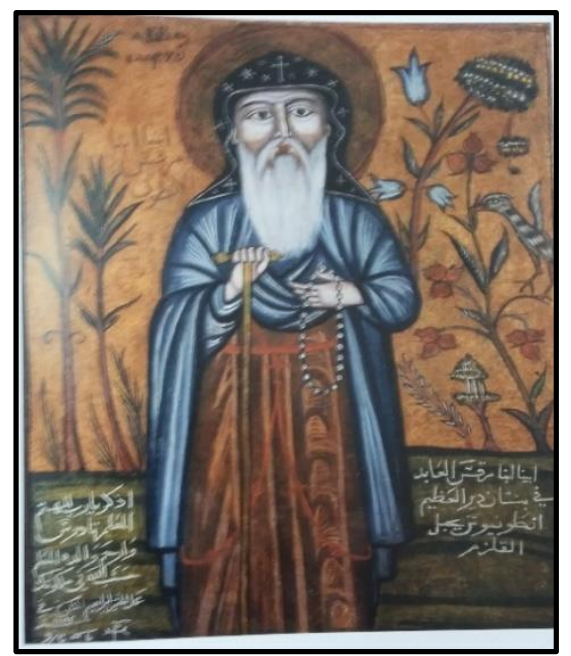

Fig.8. Markus al-Antuni carrying praying beads, signed by Ibrahim al-Nasikh, Monastery of St. Paul, Egypt, eighteenth century AD, 1768-1769 AD After: Swanson, "The Monastery of St. Paul in Historical Context," fig.2.4

The icon of St. Pachomius ${ }^{61}$ (Pakhom), father of Coenobitic Life is found in Haret ElRum in Cairo. ${ }^{62}$ The saint holds a Latin cross in the right hand and black praying beads in the left hand. The praying beads are placed between his thumb and index finger and ends with a Greek cross sign. The saint wears the black kalansuwa adorned with shapes of crosses, red mandyas, black tunic with a cross-decorated epitrachelion. (fig. 9) ${ }^{63}$.

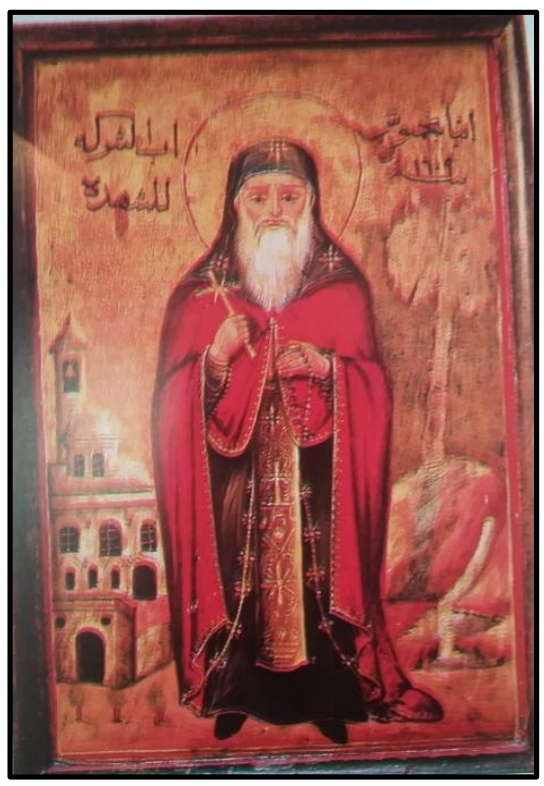

Fig. 9. Icon of St. Pachomius (Pakhom), father of Coenobitic Life, discovered in Haret El-Rum, Cairo

After: Attalah, Coptic Icons, Les Icônes Coptes, 79

Praying beads were also accompanied with St. Bishoy (Coptic Pshoi) in the Monastery of St. Bishoy in Wadi El-Natrun. ${ }^{64}$ This saint established his own community during the last year of St. Macarius the Great's life. ${ }^{65}$ His icon represents a unique iconography as the praying beads and the staff are carried in one hand, namely the left hand. The other 
hand of the saint is performing the gesture of adoration. The chain of praying beads is placed between the thumb and index of the saint's hand and ends with the cross. The saint wears a blue kalansuwa, red mandyas, a yellow tunic and a plain blue epitrachelion as well (fig.10).

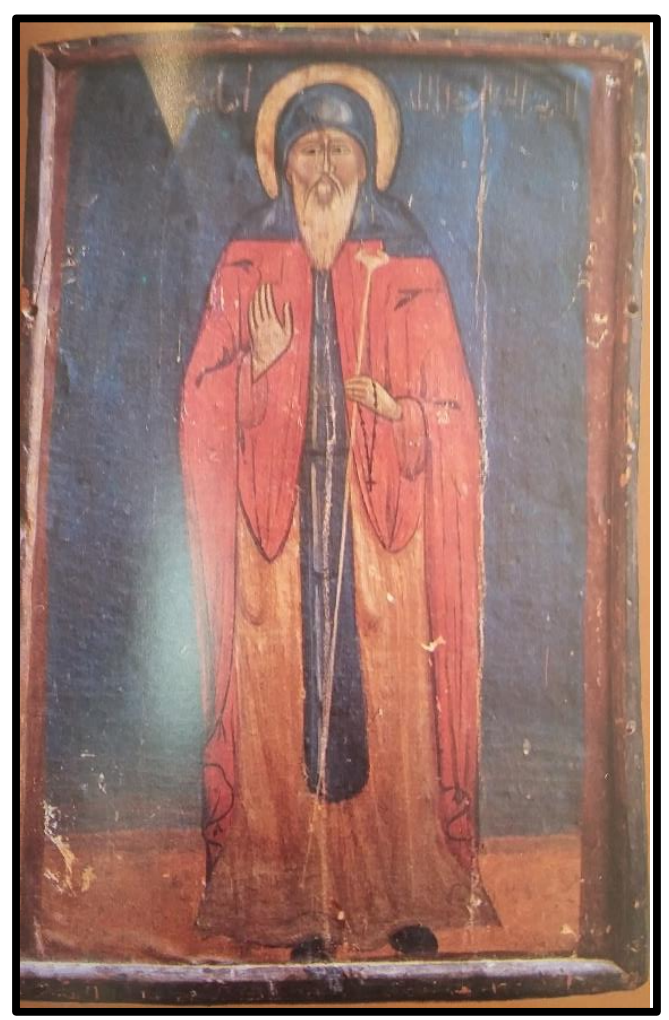

Fig.10. Icon of St. Bishoy (Coptic Pshoi) holding praying beads, Monastery of St.

Bishoy in Wadi El-Natrun

After: Attalah, Coptic Icons, Les Icônes Coptes, 95

St. Domitius, the son of the Roman emperor Valentinian I (364-373 AD), is represented holding chain of praying beads. This is portrayed on an icon from the monastery of the Holy Virgin in Dair el-Baramus in Wadi El-Natrun. ${ }^{66}$ St. Domitius is depicted standing side by side with his brother St. Maximus. A chain of praying beads is represented in the left hand of St. Domitius who holds a long tau-staff in the other hand. The artist could skillfully reflect the action of counting the pebbles by the thumb and index finger of the saint while the rest of the bead hangs around his wrist. The small oval-shaped pebbles of the praying beads are white in color. The two saints are depicted wearing a black klobuk, a blue mandyas, as well as a red tunic. (fig.11). 


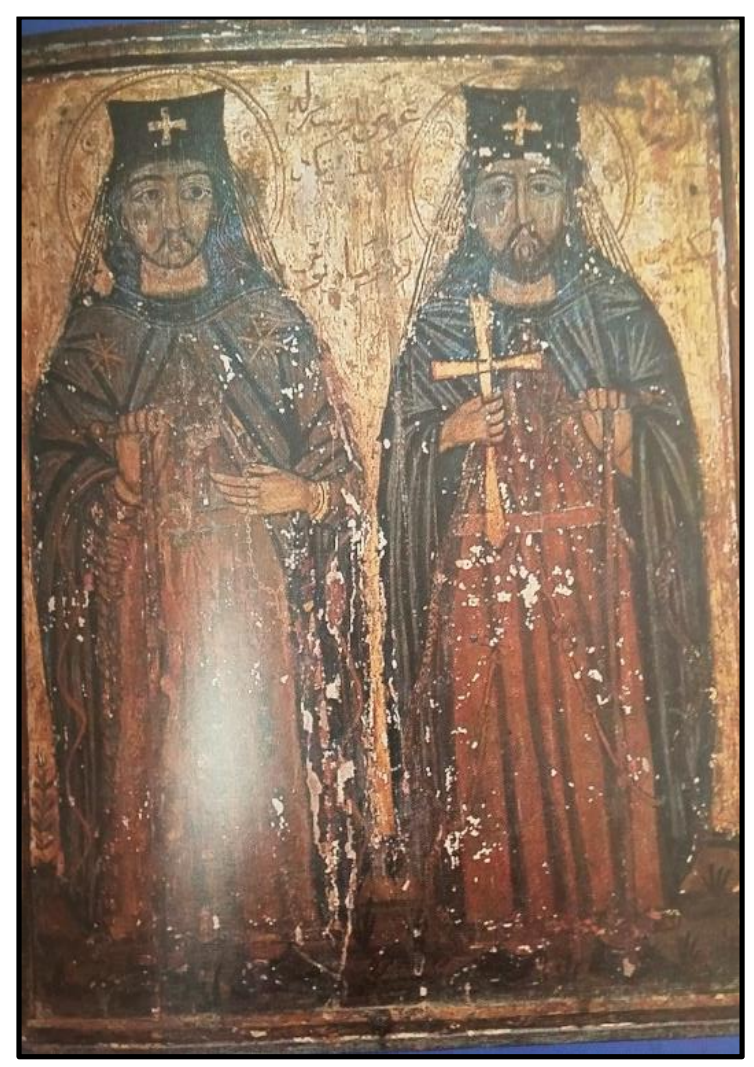

Fig.11. Icon representing St. Maximus and St. Domitius, the sons of the Roman emperor Valentinian I (364-373 AD) embracing the ascetic life. This icon is located in Dair ElBaramus in Wadi El-Natrun

After: Attalah, Coptic Icons,Les Icônes Coptes, 101.

St. Apip ${ }^{67}$, one of the founders of the ascetic community of Wadi El-Natrun is represented holding praying beads. This is shown through an icon in the monastery of the Holy Virgin in Dair El Baramus. The two Desert Fathers, namely St. Apollo (right) and St. Apip (left), are depicted as full-length standing men. ${ }^{68}$ A chain of white praying beads is depicted in the left hand of St. Apip who holds a Latin cross in his right hand. The two saints are wearing the black kalansuwa, blue mandyas, and a red tunic (fig.12). 


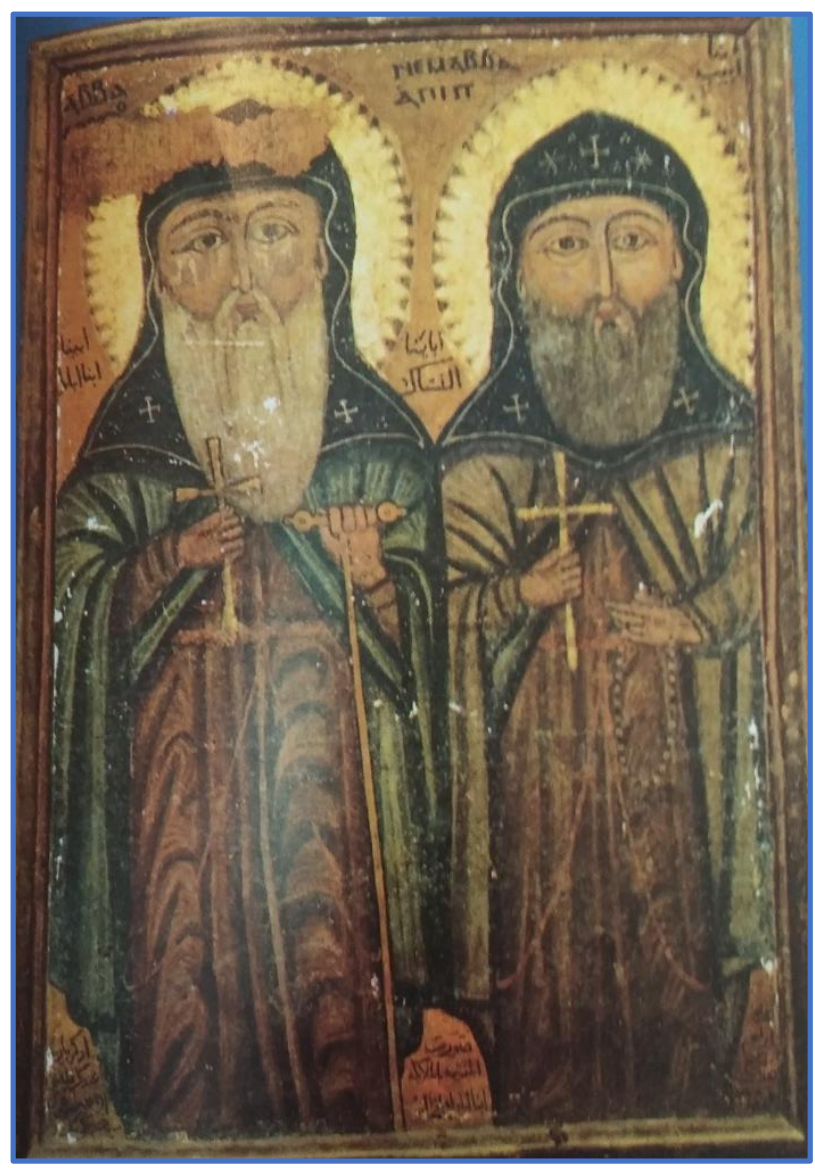

Fig.12. Icon found now in the Monastery of Dair El Baramus in Wadi El-Natrun. It depicts two Desert Fathers; St. Apollo and St. Apip

After: Attalah, Coptic Icons,Les Icônes Coptes, 99

There is an icon discovered in Upper Egypt which shows St. Hadara and his disciple; a saint who lived in the fourth- fifth century AD. ${ }^{69}$ The disciple is depicted carrying black praying beads with his right hand and a book (Holy Book?) with his left one. The pebbles are here black in color and ends with the shape of the cross. He is simply dressed in a yellow mandyas and a long blue tunic (fig.13) ${ }^{70}$. 


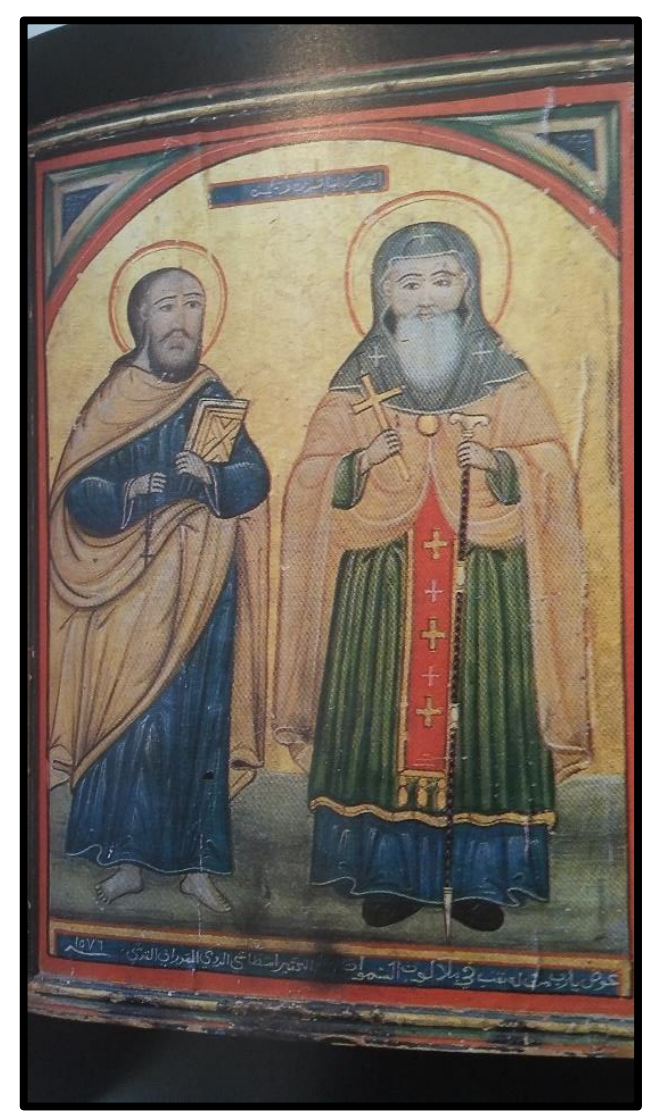

Fig.13. Icon of St. Hadara and his disciple holding chain of praying beads, Upper Egypt After: Attalah, Coptic Icons, Les Icônes Coptes, 113

In the monastery of St. Thomas the Hermit in Akhmim, there is a marvelous icon that depicts St. Thomas the Hermit and another female saint holding praying beads. ${ }^{71}$ Both of them are depicted holding white praying beads which is terminated from the middle by a Greek cross. The saint is holding his white praying beads in the right hand and a Latin cross in the other one. Concerning the female saint, she holds the same hand objects but in the opposite hands. St. Thomas wears a small cap, stripped red mandyas, and a black tunic which is barred with white lines in its lower part. Concerning the female saint, she wears a dotted black maphorion over hear head, and a simple red tunic (fig.14). 


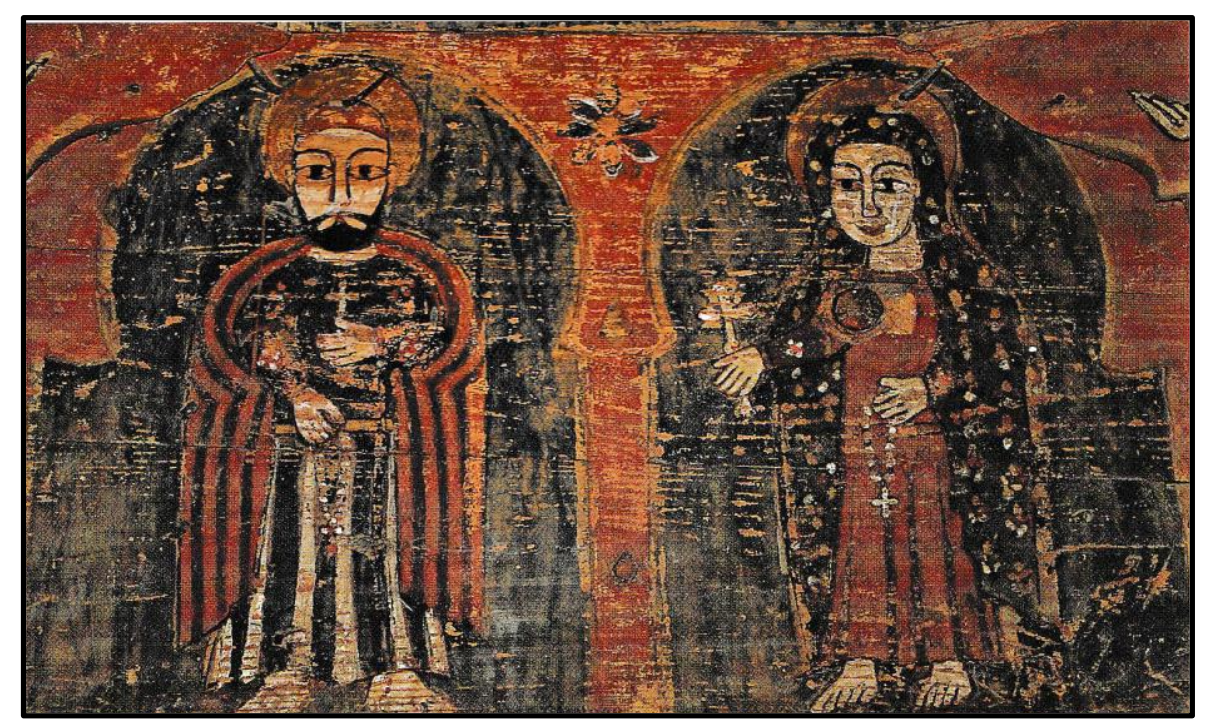

Fig.14. Icon depicting St. Thomas the Hermit carrying praying beads, Akhmim After: Zibawi, Images de l'Egypte chrétienne: iconologie copte, 215, fig. 290.

In Old Cairo, the Church of St. Cyrus (Aba Kyr) and St. John represents another example of praying beads being carried by both St. Pachomius and his sister Dalusham. ${ }^{72}$ The two siblings were known as "Martyrs of Akhmim"73. Both figures are represented holding a Latin cross in their right hands and praying beads in thee left ones. The pebbles of these beads are colored white and black alternatively and are terminated from the middle by a small pendant of beads. St. Dalusham covers her head with a yellow maphorion, and wears a red mandyas and a blue tunic tied with a belt. Concerning her brother, her wears the same dress beside the yellow epitrachelion adorned with shapes of crosses. This icon dates back to the eighteenth-century AD (fig.15).

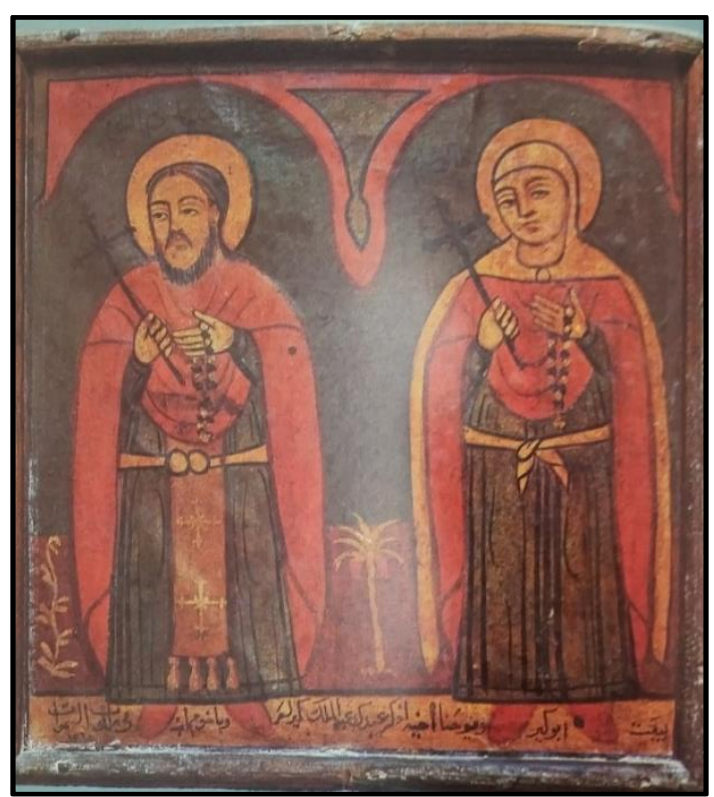

Fig.15. Icon of St. Pachomius and his sister Dalusham with their praying beads, eighteenth century AD, Church of St. Cyrus (Aba Kyr) and St. John, Old Cairo 
After: Attalah, Coptic Icons, Les Icônes Coptes, 28, 29.

Praying beads are also depicted in the hands of the three macarii. ${ }^{74}$ This iconography is found in a remarkable icon in the Church of St. Cyrus (Aba Kyr) and St. John. The piece is knolwn as "Icon of the three Saints Macarii", and dates back to the eighteenthcentury AD. The three saints are depicted holding black praying beads in their left hands and the Latin cross in their right hands. Every chain ends with the sign of the cross ending with a tassel. The three characters are shown making the adoration gesture with their left hands. The three saints are depicted simply wearing a mandyas and a long tunic. (fig.16).

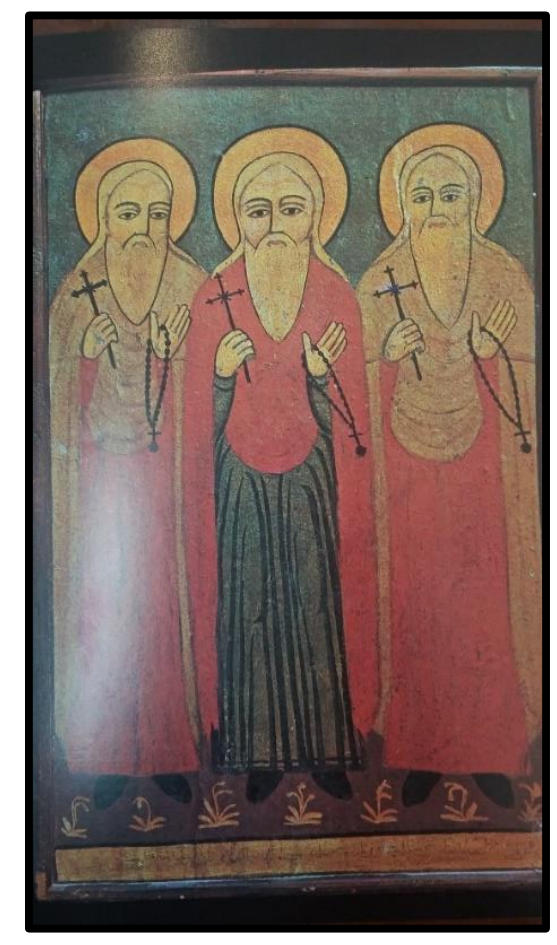

Fig. 16. The Icon of the three Macarii carrying chains of praying beads, eighteenth century AD, Church of St. Cyrus (Aba Kyr) and St. John

After: Attalah, Coptic Icons, Les Icônes Coptes, 29.

A triptych icon represents the Holy Virgin Mary in the central panel carrying the child Christ while two angels surrounding them. On the left shutter, St. Anthony is represented holding his long staff and a papyrus scroll. On the right part, while St. Paul is represented in adoration attitude with praying beads that end with a decorative cross element. The standing saint raises his two arms in praying attitude while holding praying beads with his right hand. The chain is black colored to stand for the sins of humans and ends with the sign of the cross ending with a tassel. St. Paul is shown with the sacred halo, bold and with while long beard. He is also dressed in relatively short tunic with a belt around his waist and sandals and with a humble look scene of the virgin and the infant Christ (fig. 17) ${ }^{75}$. 


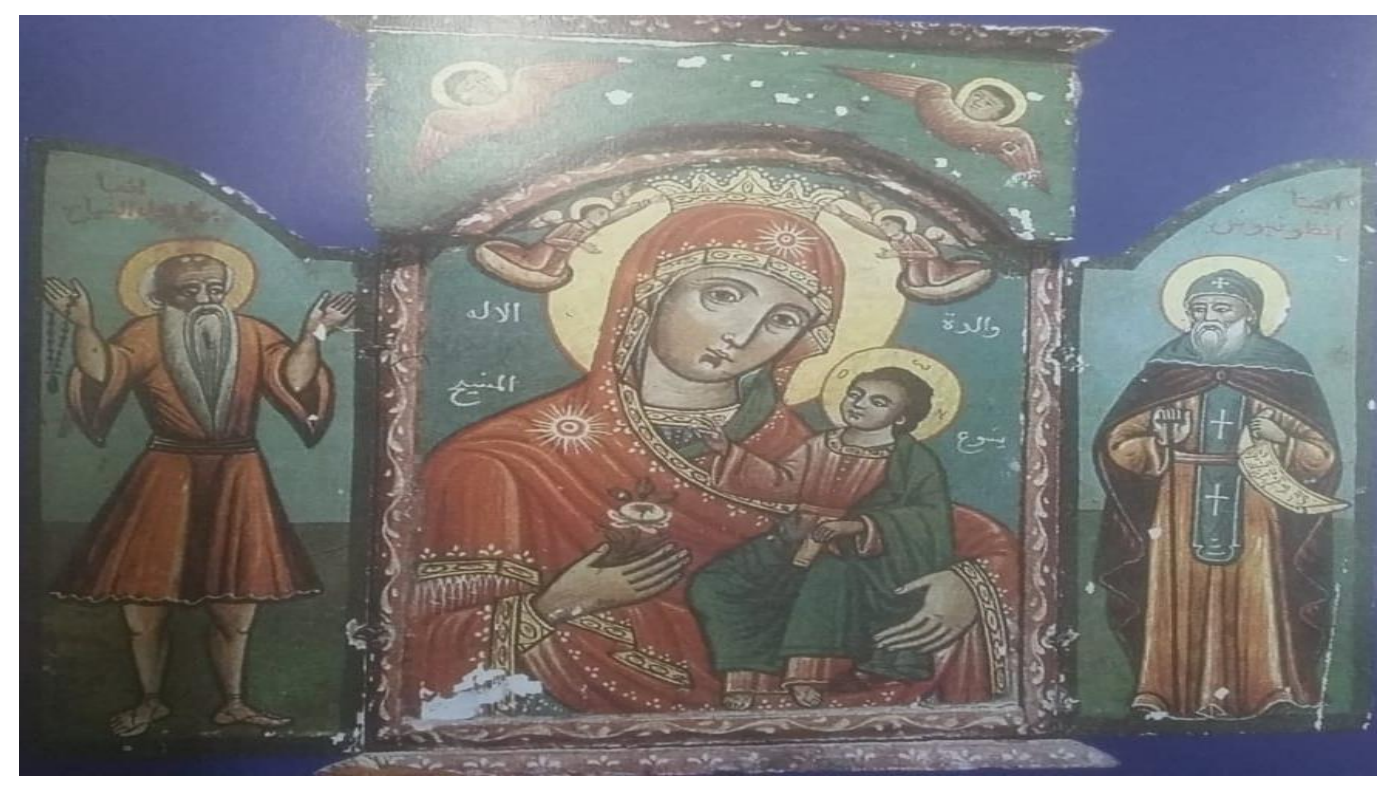

Fig. 17. A triptych icon, In the middle panel Holy Virgin Mary "Hodegteria" is represented carrying the infant Christ. To the left St. Anthony is represented while St. Paul is represented to the right in adoration attitude. After: Attalah, Nabil Selim, Coptic Icons, Cairo, Egypt: Lehnert \& Landrock, 1998, 48

Another icon represents Holy Virgin Mary carrying the child Christ and flanked by the two standing saints, St. Paul to the left and St. Anthony to the right. The saints are holding praying black ropes with the same previous style of decoration; the praying ropes end with the sign of the cross topped by a tassel. St. Paul is holding a Latin cross with his right hand and St. Anthony is holding a staff. Both of the cross and the staff were associated with the depiction of praying beads and praying ropes (fig. 18) ${ }^{76}$. 


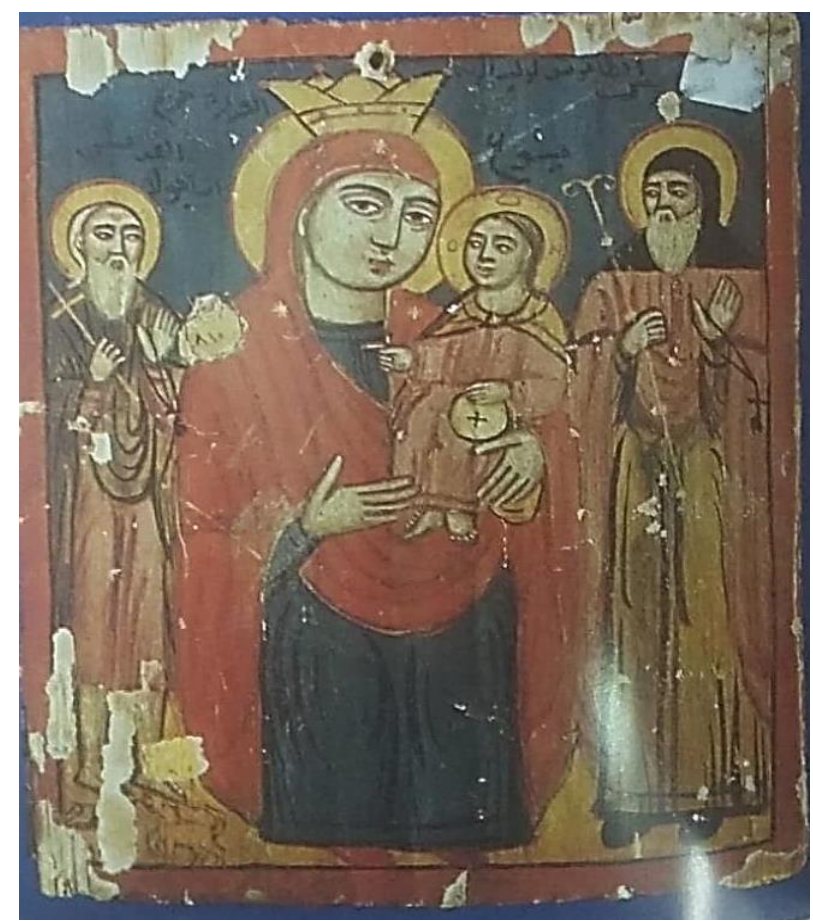

Fig. 18. Icon represents the Holy virgin Mary carrying the child Christ and flanked by the two saints; St. Paul and St. Peter, preserved in St. Anthony monastery, Eastern desert, Red Sea

After: Attalah, Coptic Icons, 22

Another triptych portrays St. George in the central panel as a knight saint smiting the evil represented in the beneath dragon. To the right a desert father probably Apa Nofer the Hermit is represented in adoration position, half naked and with long white hair and beard. To the left, there is another representation of an unidentified saint who is depicted holding praying beads along with a T-shaped staff (fig. 19) ${ }^{77}$.

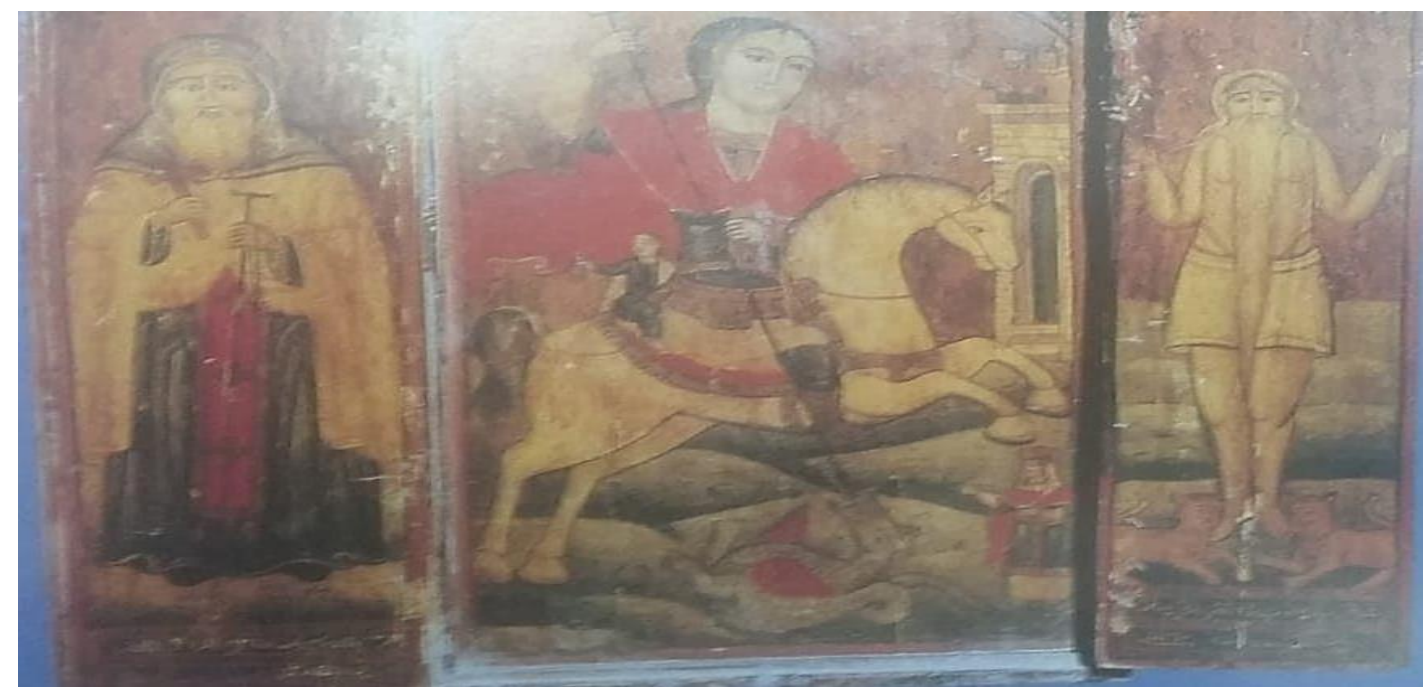

Fig. 19. A Coptic triptych icon representing St. George in the middle and two desert fathers on the two sides, Dair El Naghamish, Balyanaa district (East side of the Nile). After: Attalah, Coptic Icons, 60 


\section{Analytical Study:}

\begin{tabular}{|c|c|c|}
\hline 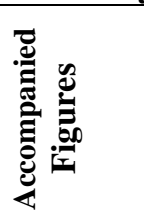 & & \\
\hline 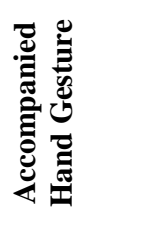 & 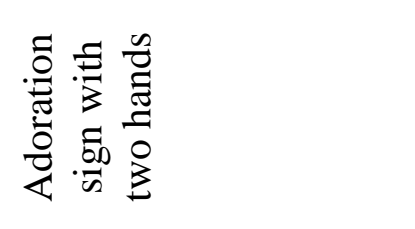 & 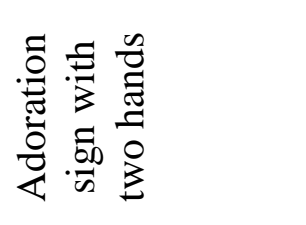 \\
\hline 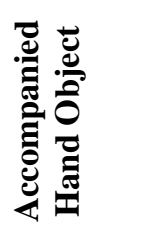 & & \\
\hline 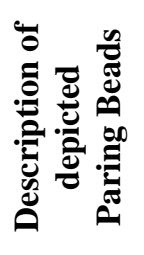 & 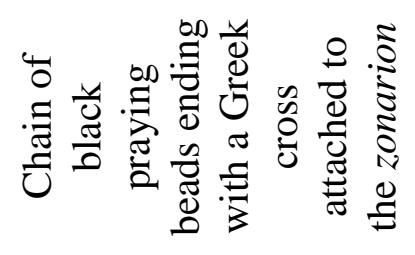 & 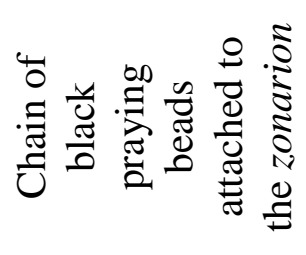 \\
\hline 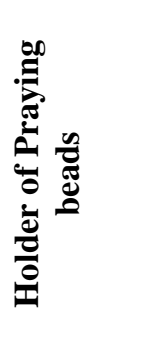 & 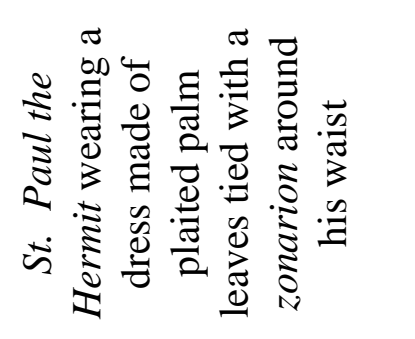 & 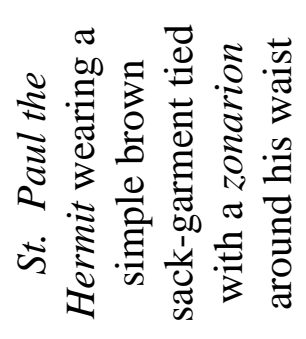 \\
\hline 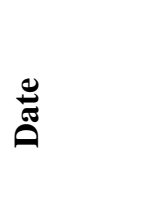 & 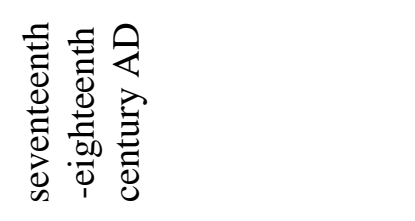 & 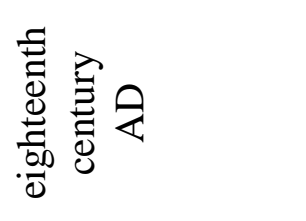 \\
\hline 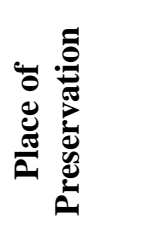 & 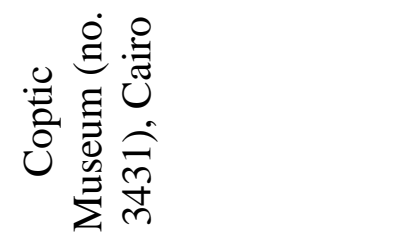 & 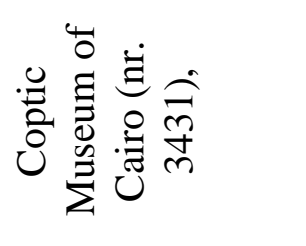 \\
\hline 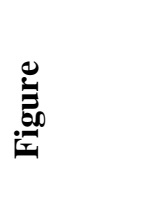 & 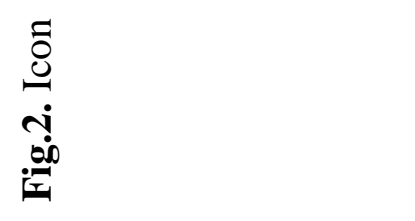 & 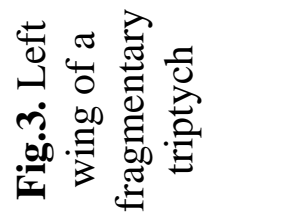 \\
\hline
\end{tabular}




\begin{tabular}{|c|c|c|}
\hline 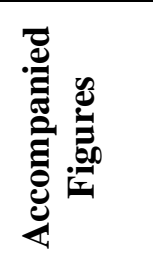 & 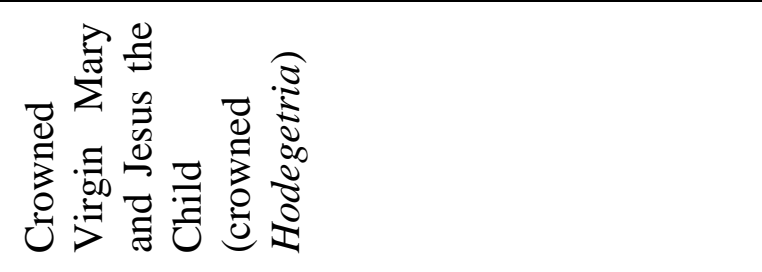 & 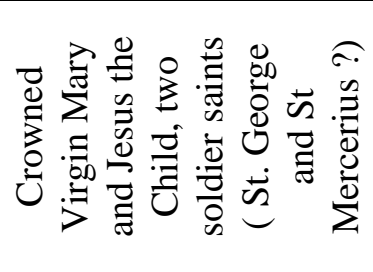 \\
\hline 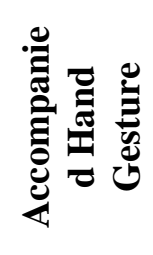 & 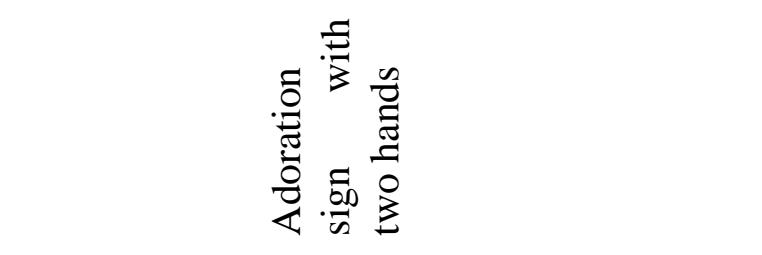 & \\
\hline 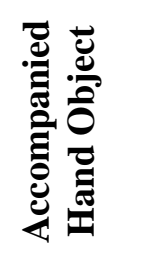 & 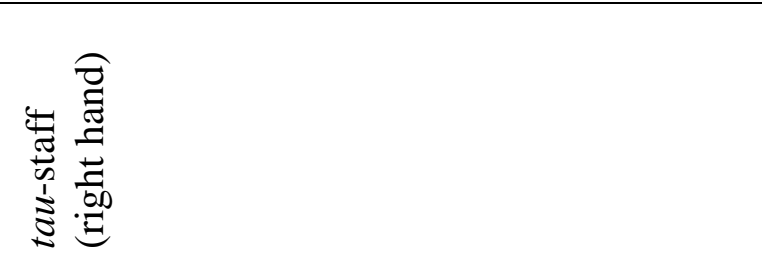 & 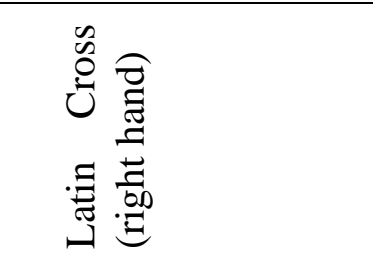 \\
\hline 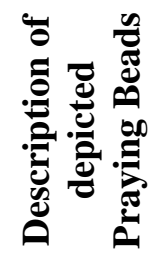 & 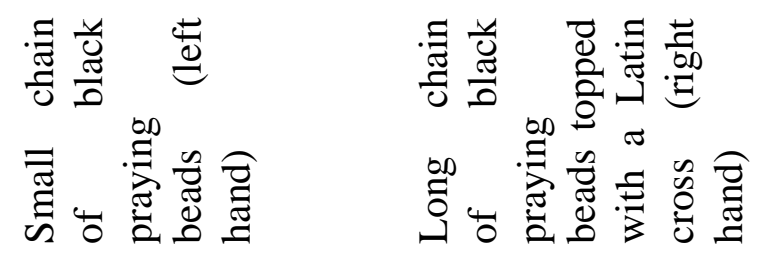 & 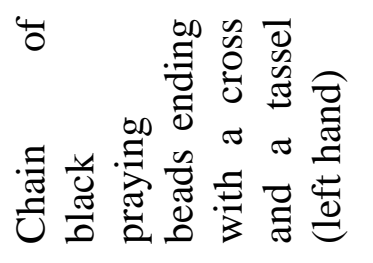 \\
\hline 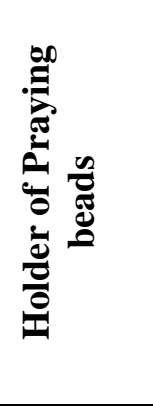 & 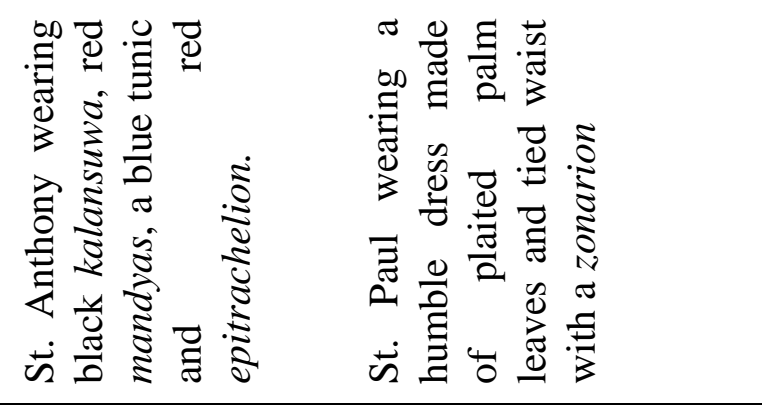 & 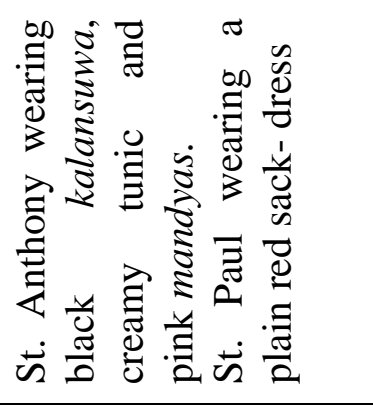 \\
\hline$\stackrel{\mathscr{I}}{\tilde{\Xi}}$ & & 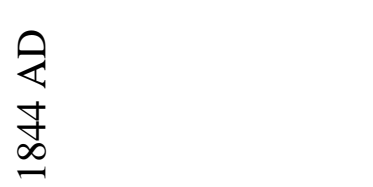 \\
\hline 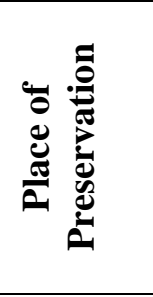 & 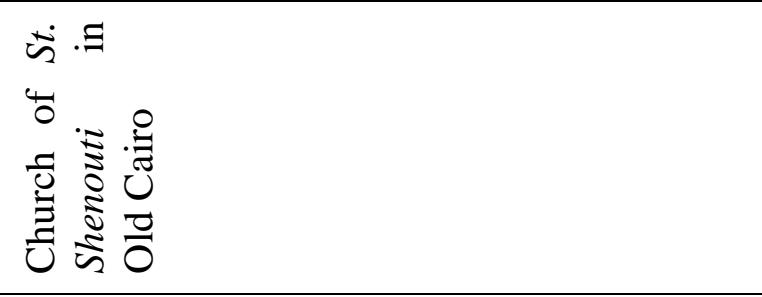 & 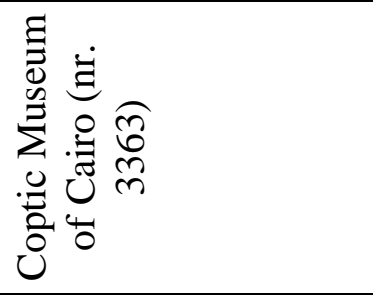 \\
\hline 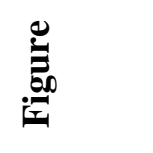 & 萬苍 & 畠 \\
\hline
\end{tabular}




\begin{tabular}{|c|c|c|c|}
\hline 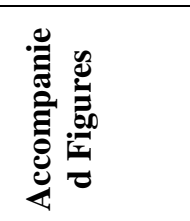 & 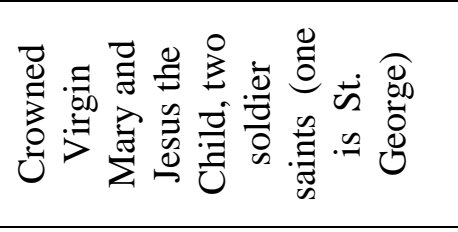 & & \\
\hline 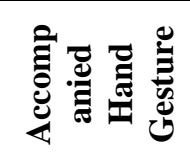 & & & \\
\hline 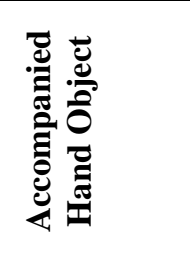 & 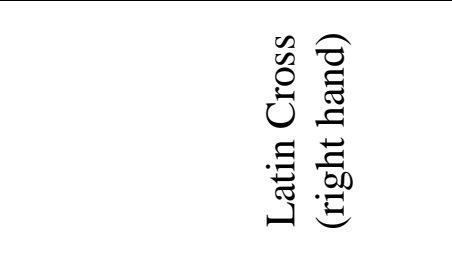 & 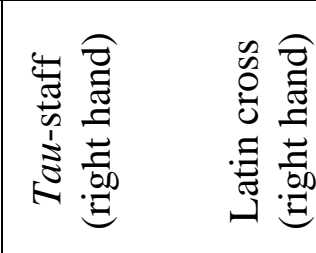 & 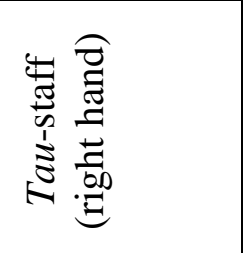 \\
\hline 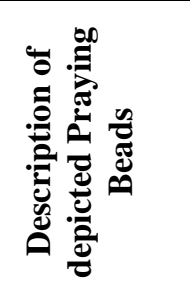 & 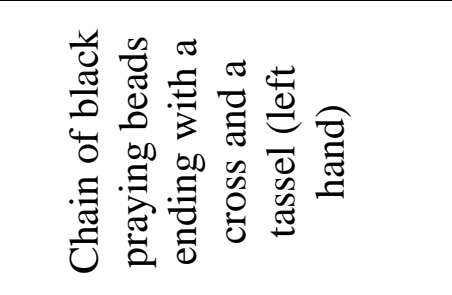 & 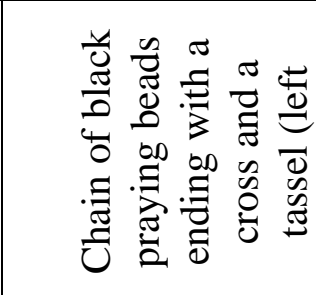 & 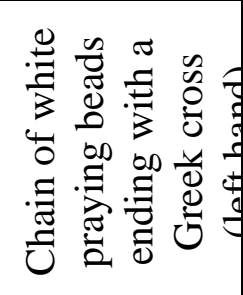 \\
\hline 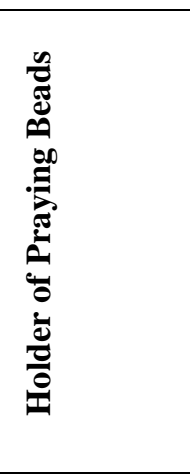 & 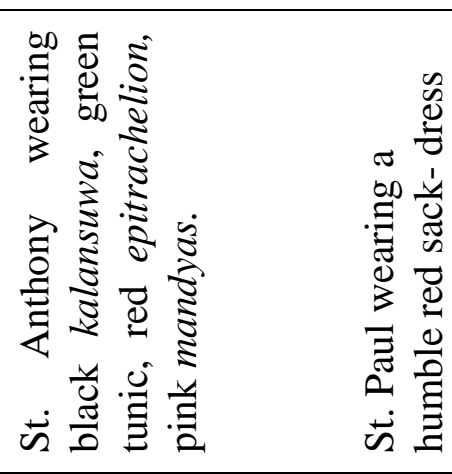 & 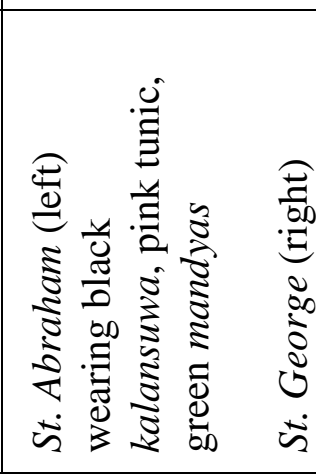 & 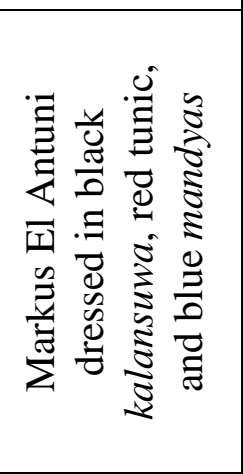 \\
\hline 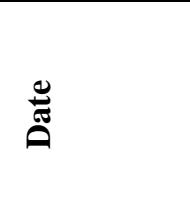 & 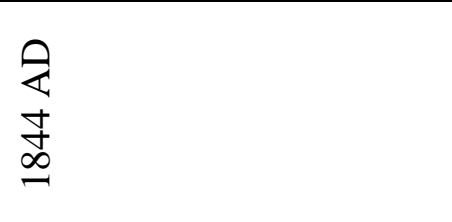 & 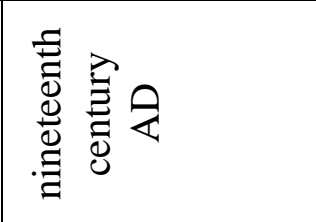 & 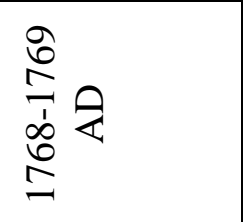 \\
\hline 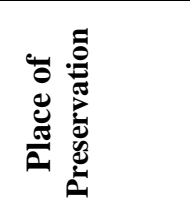 & 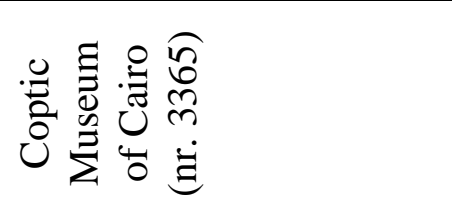 & 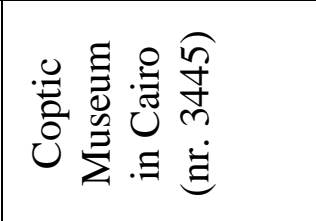 & 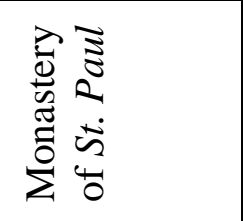 \\
\hline 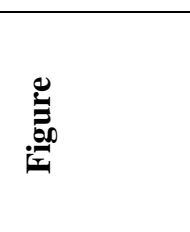 & 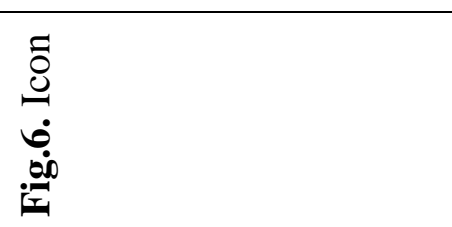 & 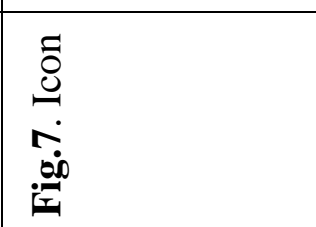 & 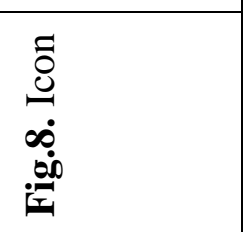 \\
\hline
\end{tabular}




\begin{tabular}{|c|c|c|c|c|}
\hline 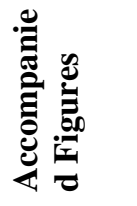 & & & 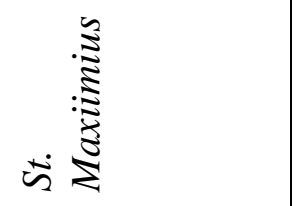 & 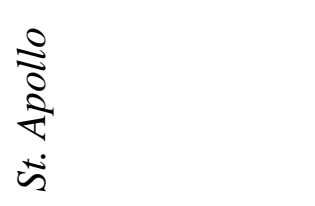 \\
\hline 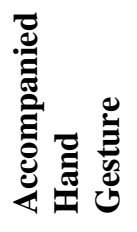 & & 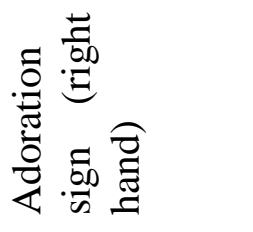 & & \\
\hline 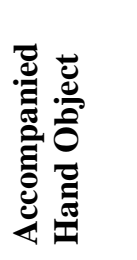 & 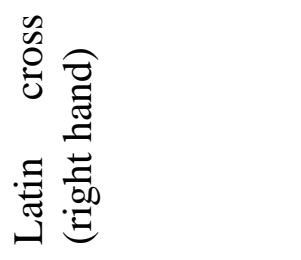 & 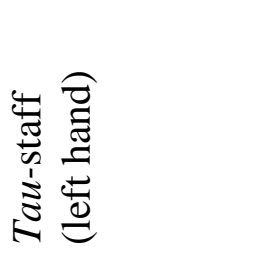 & 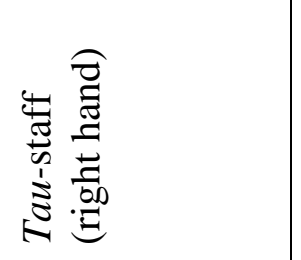 & 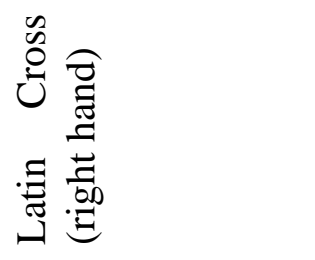 \\
\hline 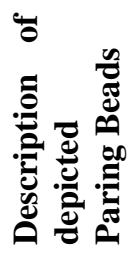 & 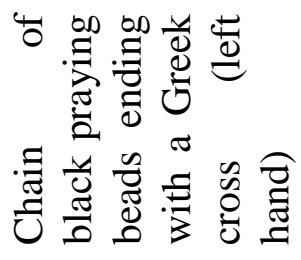 & 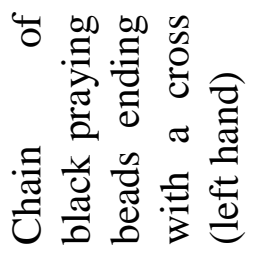 & 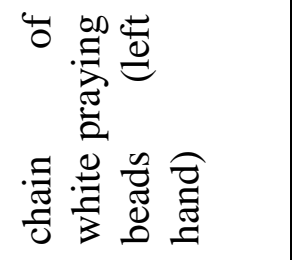 & 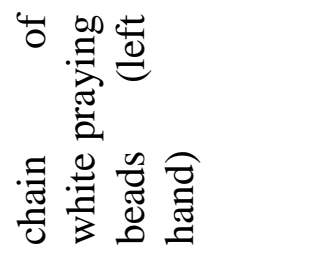 \\
\hline 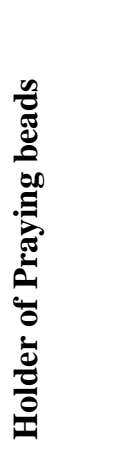 & 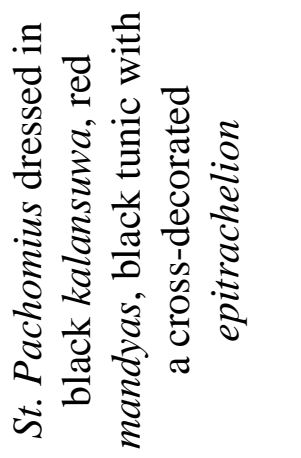 & 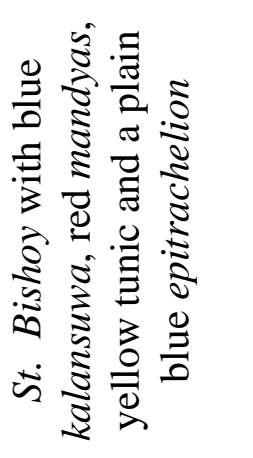 & 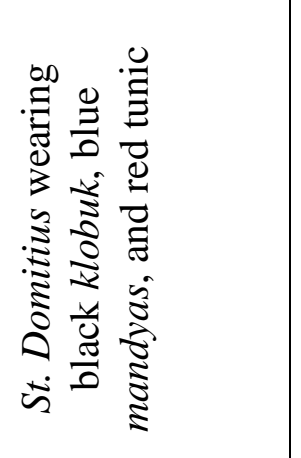 & 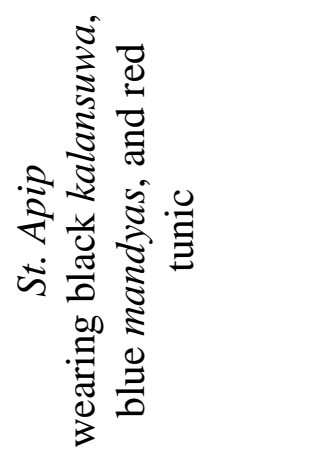 \\
\hline \multicolumn{5}{|l|}{$\frac{\mathscr{\Xi}}{\mathrm{a}}$} \\
\hline 范 & 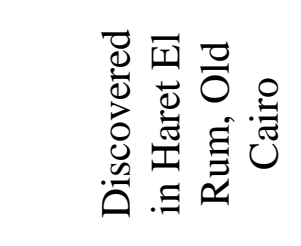 & 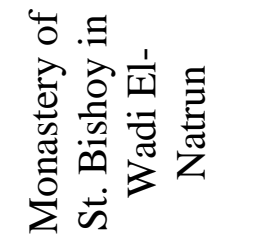 & 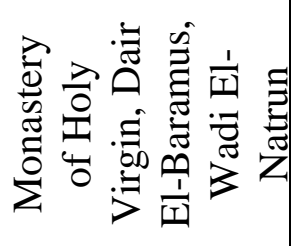 & 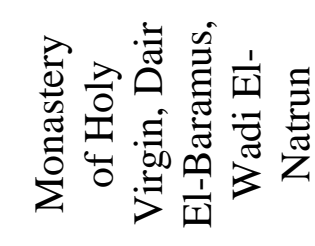 \\
\hline 苞 & 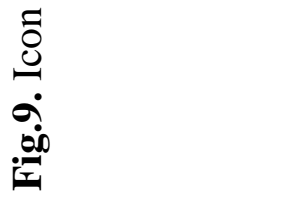 & $\underset{\dot{\theta}}{\stackrel{\dot{\theta}}{\dot{0}}}=$ & 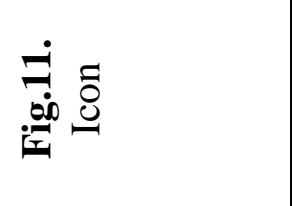 & 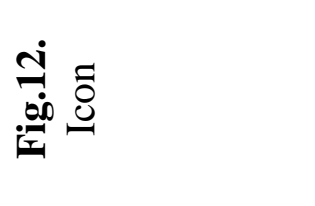 \\
\hline
\end{tabular}




\begin{tabular}{|c|c|c|c|}
\hline 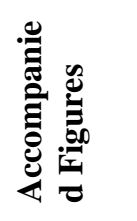 & 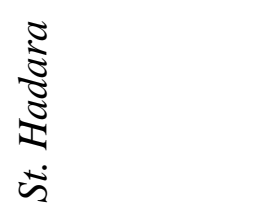 & & \\
\hline 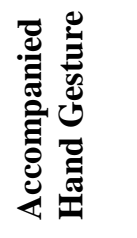 & & & \\
\hline 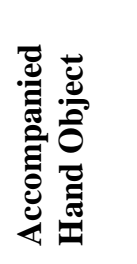 & 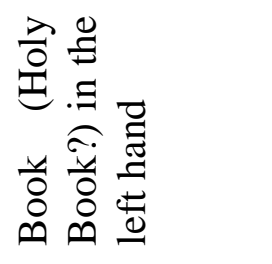 & 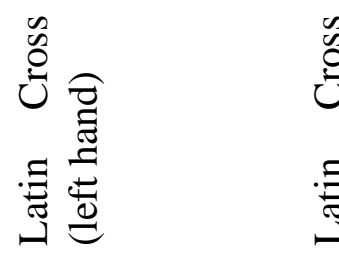 & 害 \\
\hline 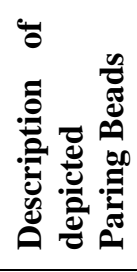 & 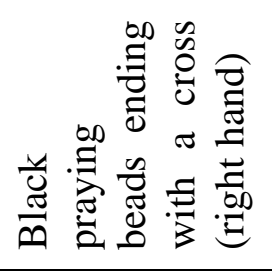 & 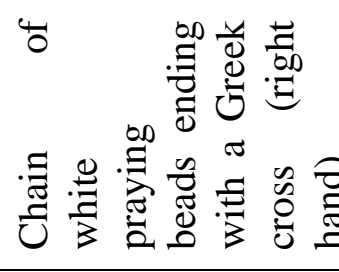 & 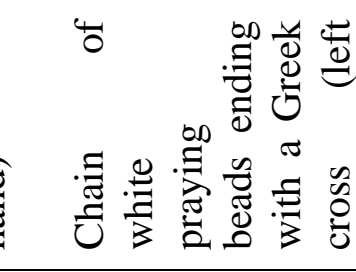 \\
\hline 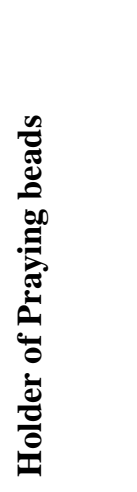 & 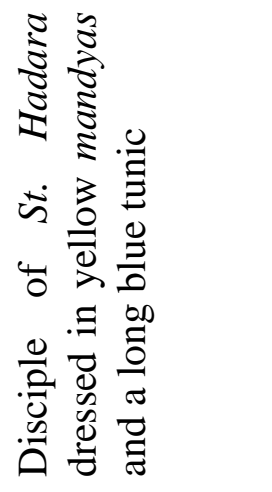 & 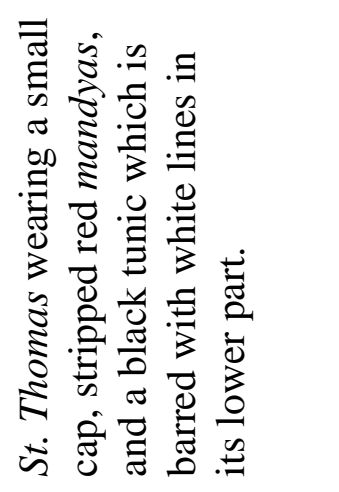 & 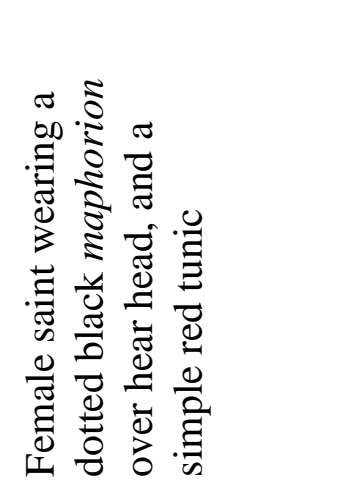 \\
\hline \multicolumn{4}{|l|}{ 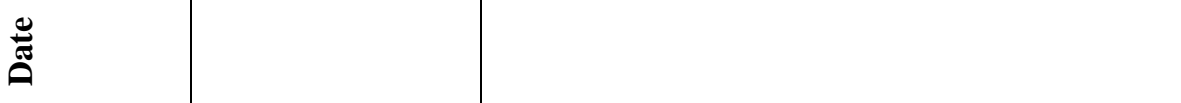 } \\
\hline 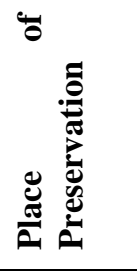 & 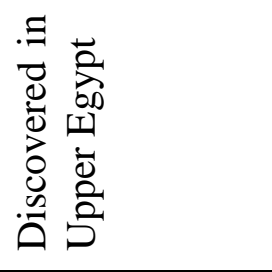 & 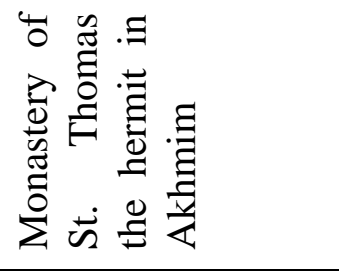 & \\
\hline 峁 & 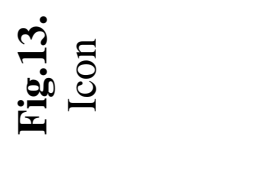 & 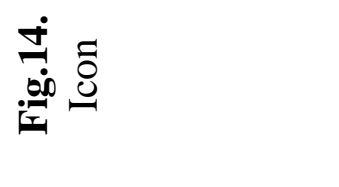 & \\
\hline
\end{tabular}




\begin{tabular}{|c|c|c|}
\hline 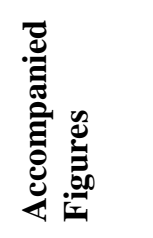 & & \\
\hline 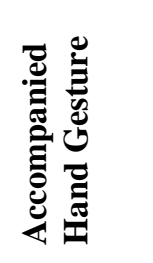 & & 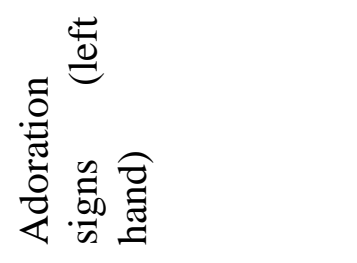 \\
\hline 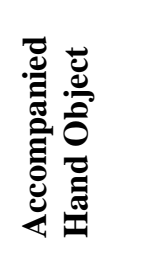 & 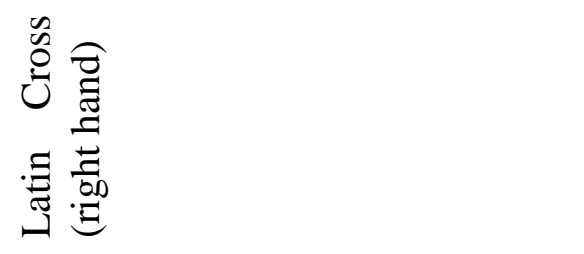 & 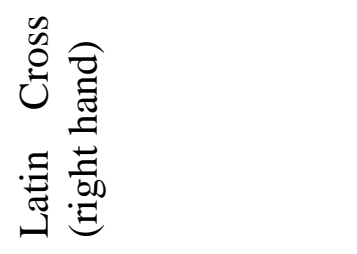 \\
\hline 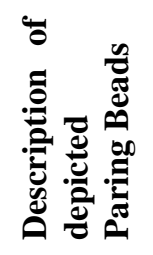 & 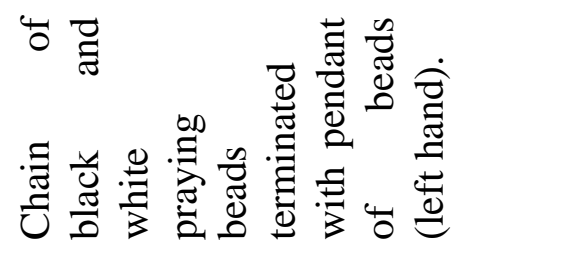 & 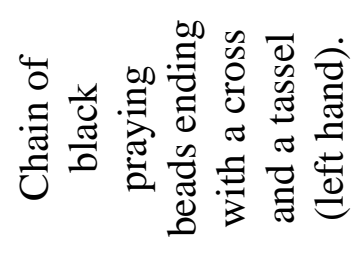 \\
\hline 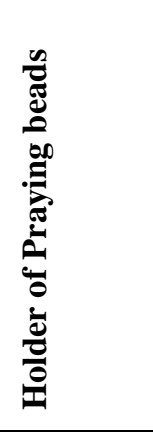 & 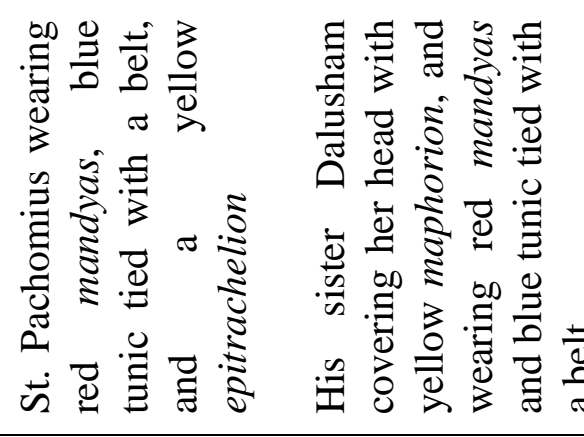 & 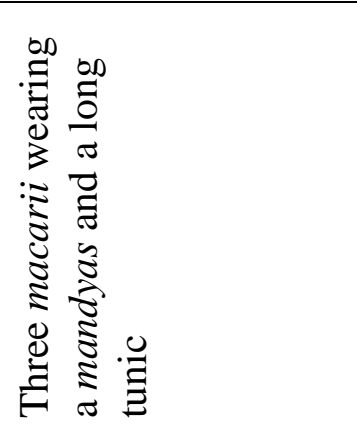 \\
\hline$\stackrel{\Xi}{\tilde{\Xi}}$ & 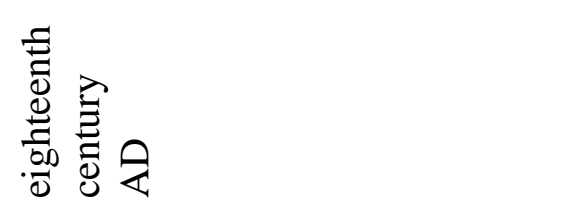 & 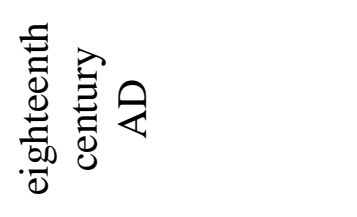 \\
\hline 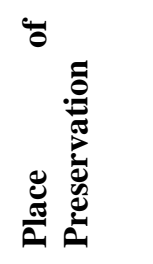 & 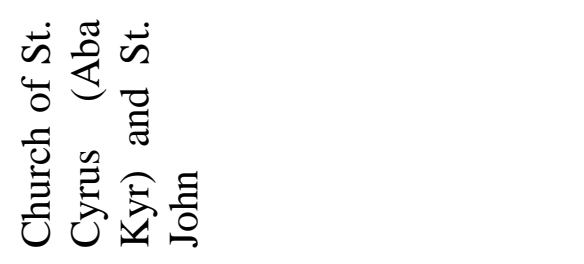 & 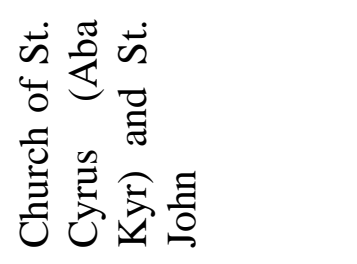 \\
\hline 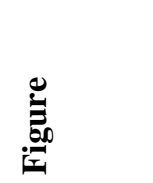 & 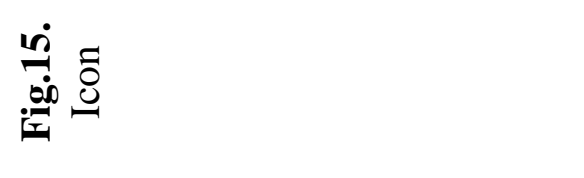 & 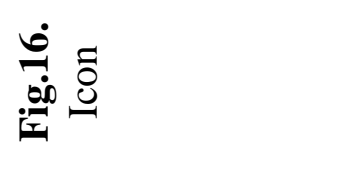 \\
\hline
\end{tabular}




\begin{tabular}{|c|c|c|c|}
\hline 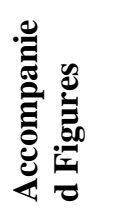 & & 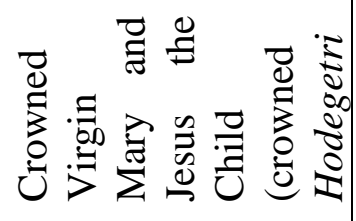 & 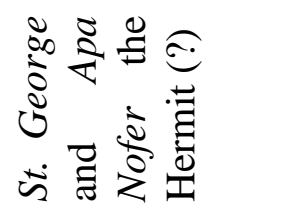 \\
\hline 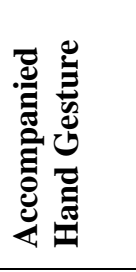 & 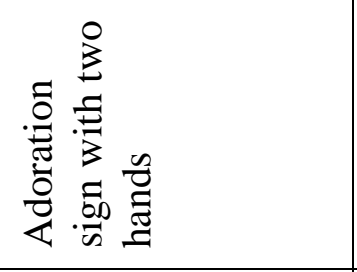 & 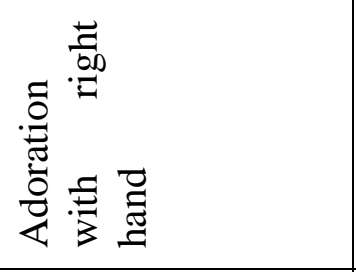 & \\
\hline 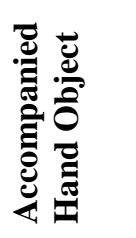 & & 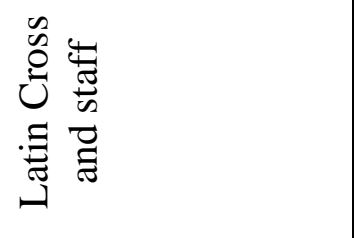 & 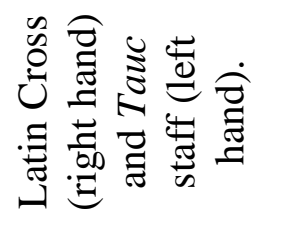 \\
\hline 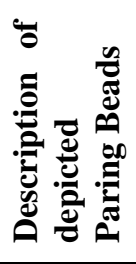 & 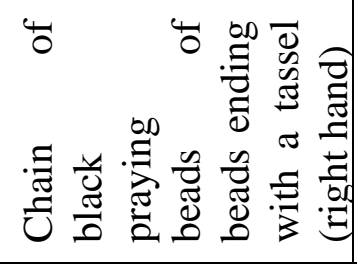 & 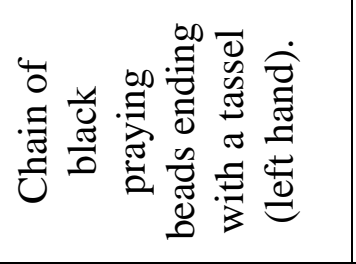 & 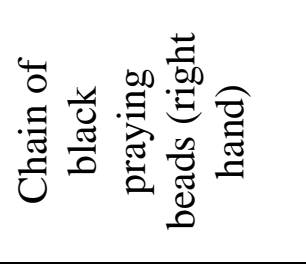 \\
\hline 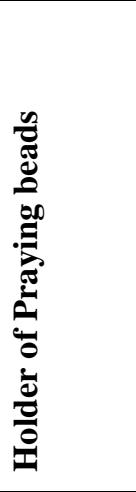 & 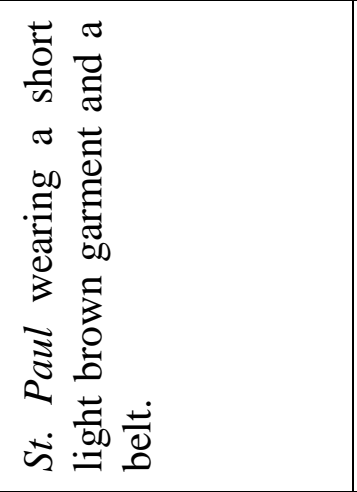 & 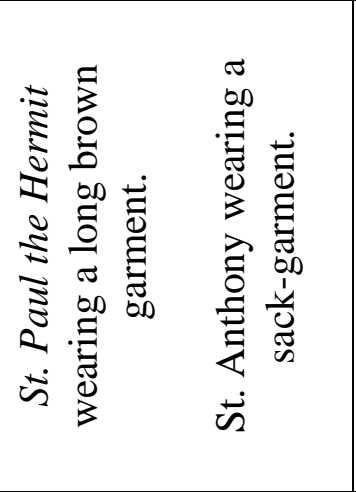 & 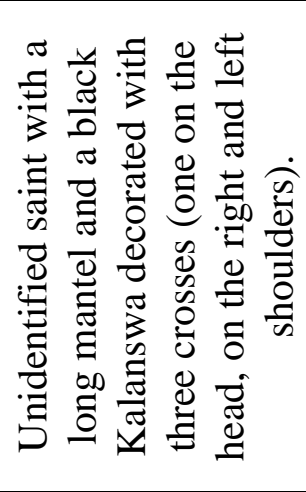 \\
\hline \multicolumn{4}{|l|}{$\stackrel{\mathscr{2}}{\tilde{\nu}}$} \\
\hline 范 & & 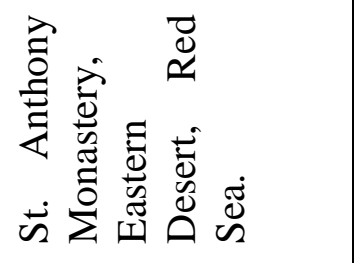 & \\
\hline 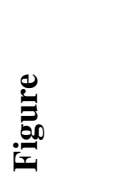 & 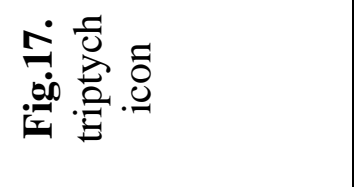 & $\underset{0}{\stackrel{\infty}{\infty}}$ & 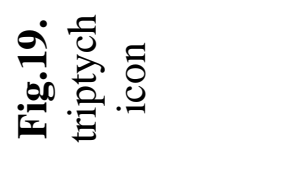 \\
\hline
\end{tabular}




\section{According to the previous table, certain points could be noticed:}

4.1. Praying beads and ropes are depicted on a large scale in Coptic art. However, it is sometimes difficult to identify if the represented hand object is a praying rope or praying beads. This is because of painting them in small size with indistinct details. In one icon, the depicted hand object could be rather identified to be a prayer rope (fig.7). In this piece, the knots of both ropes carried by St. Abraham and St. George are visible.

4.2. Praying beads and ropes became one of the remarkable hand objects depicted in Coptic icons. Being connected with the concept of monasticism in Egypt. These objects were represented being carried in the hands of the saint and monks. Several examples of St. Paul show the saint solemnly carrying praying beads. Together with St. Paul, St. Anthony is depicted holding praying beads and ropes in other examples (figs. 4, 5, 6, 18). Moreover, St. Pachomius was depicted holding praying beads twice. The first example represented him alone (fig. 9). In the second icon (fig. 15), both the saint and his sister Dalusham are using their praying beads.

In addition, other saints were depicted carrying praying beads. Coptic Icons show St. Abraham with St. George (fig.7), St. Markus el-Antunini (fig. 8), St. Bishoi (fig. 10), St. Domitius (fig. 11), St. Apip (fig.12) and St. Thomas the Hermit (fig. 14) are holding their praying beads. Less prominent figures are represented with praying beads. For instance, the disciple of St. Hadara is holding the praying beads in one example (fig. 13). Another icon shows and the female saint accompanying Thomas the Hermit with praying beads (fig. 14).

4.3. Other prominent characters are illustrated beside the holder of praying beads and ropes. The crowned Virgin Mary and her child are depicted mainly with St. Anthony and St. Paul the Hermit while carrying their chain of beads (figs. 4,5,6, 18). This iconography, known in art as crowned Hodegetria, reveals the importance of the praying beads which enable the user to reach the highest levels of piety. Furthermore, the beads' carrier was sometimes accompanied with another character who was known to be deeply connected to him. St. George appeared with both St. Paul and St. Anthony (figs. 5, 6, 19). St. Maximius was depicted side by side with his brother St. Domitius (fig.11), St. Apip was illustrated with St. Apollo (fig.12), and the disciple of St. Hadara was represented with him in one example (fig.13).

4.4. The carrier of the praying beads could be one, two, or even three. Certain examples represent two saints holding praying beads such as; St. Paul and St. Anthony (figs. 4, 5, 6, 18), St. Abraham and St. George (fig.7), St. Thomas and the female saint (fig.14), St. Pachomius and his sister Dalusham (fig. 15). The three macarri are illustrated in one example holding praying beads (fig. 16).

4.5. The majority of the represented beads' carriers are dressed in the traditional monastic costumes including the kalansuwa, the mandyas, the long tunic as well as the epitrachelion. The kalansuwa is replaced with the shape of a black klobuk worn by St. Domitius (fig. 11), and by small cap worn by St. Thomas (fig.14). The female saints covered their heads with the maphorion (figs.14, 15). 
4.6. In the case of being accompanied with hand gestures, the adoration sign was the solemn hand gesture being represented with praying beads and ropes. This gesture was either made by raising the two hands or only one hand. St. Paul is the only saint who was depicted making the adoration sign with his both hands and carrying his chain of praying beads (figs. 2, 3, 4, 17). In other examples, this hand object was carried in one hand while raising the other hand in adoration; a gesture pose that is illustrated on the icon of St. Bishoi (fig.10). In the icon of the three Macarii, the three figures are making the adoration gesture with the same hand that holds praying beads (fig. 16).

4.7. In some cases, praying beads were depicted side by side with other hand objects. For instance, examples show praying beads and ropes being accompanied Latin Cross (figs. 5, 6, 7, 9,12,14,15,16, 18, 19). The cross might refer to the cross gesture done with the right hand while using the left hand in carrying the praying beads and ropes. Other icons show the tau- staff carried with praying beads (figs. $4,7,8,10,11,19)$; a crucial staff which was particularly used by the monks. Among these icons, only one icon, namely that of St. Bishoy represents him holding the two objects with the same hand (fig. 10). One icon depicts a book, most probably the Bible, being carried by the disciple of St. Hadara (fig. 13).

4.8. In Coptic Culture, praying beads were held in the left hand while making the sign of the cross with the right hand. Thus, the majority of Coptic icons represent praying beads and ropes being carried in the left hand (figs. 4, 5, 6, 7, 8, 9, $10,11,12,14,15,16,18)$. However, the artist did not restrict himself in this iconography as other icons represent praying beads in the right hand of the worshippers (figs. 4,13,14, 17, 18, 19). Icons of St. Paul present a unique iconography of praying beads being tied with his liturgical belt (zonarion) around the waist beneath his left arm (figs. 2,3,4). Being confined to St. Paul, the artist apparently intended to reveal that praying beads and ropes were an indispensable hand object of this saint.

4.9. The pebbles and knots were mainly black, white, or rarely white and black strung on a cord alternatively. Black praying beads represent the majority of the examples (figs. 2, 3, 4, 5, 6, 7, 10, 13, 16, 17, 18, 19). White colored beads found in certain examples (figs. 8, 11, 12, 14). The icon of St. Thomas the hermit in Akhmin represents a remarkable shape of praying beads which consists of black and white pebbles (fig. 14).

4.10. The figure of the cross is depicted terminating the praying beads from the middle (figs. 2, 5, 6, 7, 8, 9, 10, 11,14,15). In some examples, the depicted cross could be identified as Greek cross (figs. 2, 8, 9,14). Other icons depict the chain of beads being terminated with a tassel (fig. 5,6,7,16,17, 18). There is a distinguished shape of praying beads which end with the shape of a cross topped by a tassel. This is depicted being carried by St. Paul and St. Anthony (fig. 5,6), St. Abraham and St. George (fig.7) and by the three Macarii (fig. 16). Another example (fig. 15) shows the chain of beads being terminated from the middle with a small cord of beads.

4.11. Many Coptic icons bearing the shapes of praying beads are found in the Churches of Old Cairo (figs. 2, 3, 4, 5, 6, 7, 9, 15, 16) as well as the monasteries of Wadi El- 
Natrun (figs. 10,11,12). Furthermore, certain icons from the churches of Upper Egypt (figs. 13,14) the monastery of St. Paul (fig. 9) and the monastery of St. Anthony (fig. 18) reveal the shape of praying beads.

4.12. Almost all examples date back to the late Coptic art, as early as the seventeenth till the nineteenth centuries AD.

\section{Praying Beads and Praying Ropes in the Context of Modern and Coptic Heritage}

Praying beads maintained to be a crucial element in the monastic life in Egypt as far as the Ottoman period. There is a remarkable painting, apparently executed by an Armenian painter, for an Egyptian monk on his way to the monastery of St. Anthony. The monk wears the traditional Ottoman costume, a blue turban, and red shoes. ${ }^{78} \mathrm{He}$ is depicted walking and holding a staff in his right hand and a black praying bead in his left hand. Three beads topped by the Greek cross terminated suspend from the middle of the praying beads (fig. 20).

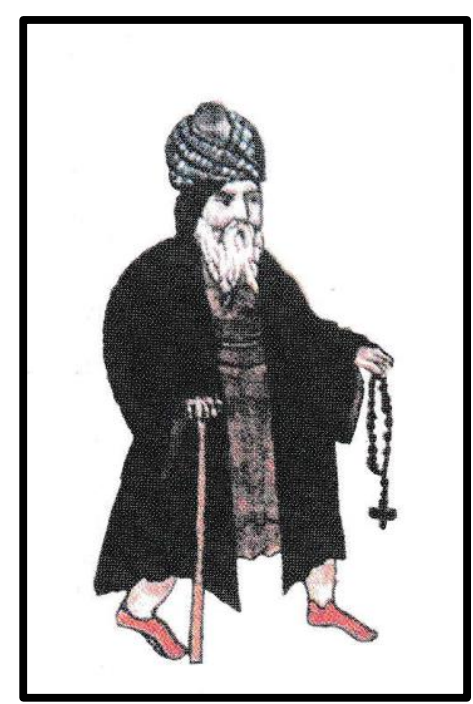

Fig.20. Ottoman drawing of an Egyptian Monk holding a praying bead and going to the Monastery of St. Anthony

After: Zuzana Skalova, Gawdat Gabra, Icons of the Nile Valley, Cairo: Egyptian international publishing-Longman, 2006, 120.

Nowadays, praying beads were still used by the monks in monasteries. It became a tangible element ${ }^{79}$ of the Coptic heritage in Egypt. Moreover, praying beads and ropes help in preserving a crucial intangible element ${ }^{80}$ in the Coptic heritage, namely the recited prayers. ${ }^{81}$ However, using such beads are not restricted to monks but they could also be used by common Christians. Praying beads help in clearing the mind of their user to concentrate during his devotion away from any distraction leaving behind his back the earthly worries. Thus, praying beads are used as a training tool for the monks to recite their prayers even in their subconscious. They are particularly used by new monks to recite "Jesus Prayers" and trying to involve all their senses in this action. They count their prayers on the beads while reciting them vocally. Elder monks recommend to place an iconography of the crucified Jesus in front of the monk during 
recitation. By this way, sight, hearing, as well as touch senses are involved during using praying beads aiming to reach the highest level of concentration.

Recited prayers are named in Arabic "El-Salah Sahmeya" meaning "prayers of arrows" referring to their role in warding off the demon. In ancient times, as soon as the person was accepted as a monk, praying beads were presented to him. Nevertheless, this tradition is not attested nowadays. Forty-one beads and one hundred beads of praying are now manufactured in certain monasteries. The first one is used to recite "Kyrie Elesion" individually by the monks. Concerning the one hundred beads of praying, it is used to recite the same phrase during Good Friday in churches. During that day, the leader preach holds the praying beads to aid him in keep counting the prayers and the attended audience recite after him. By the end of Good Friday, "Kyrie Elesion" is recited as a liturgical prayer four hundred times in the church. Every one hundred is recited in the a direct of the four main directions of the church starting from east, west, north, and ending in the southern part of the church.

Aside from the previous-mentioned prayers, praying beads could be used in any time or place without being restricted to a certain number of prayers. Since ancient times, there were no restriction in the materials used in making Coptic praying beads. Wood, particularly wood of olive trees was used to make the beads which were strung in ropes. This tradition maintained in modern times. Modern Coptic praying beads and praying ropes are now preserved in the museum of Deir El-Surian in Wadi El-Natrun. According to the displayed examples, different shapes of crosses were used in manufacturing modern praying beads. In the first example (fig.21), the thirty-three beads are made of olive wood while the Greek cross is made by four black spiral strings of a material, apparently leather.

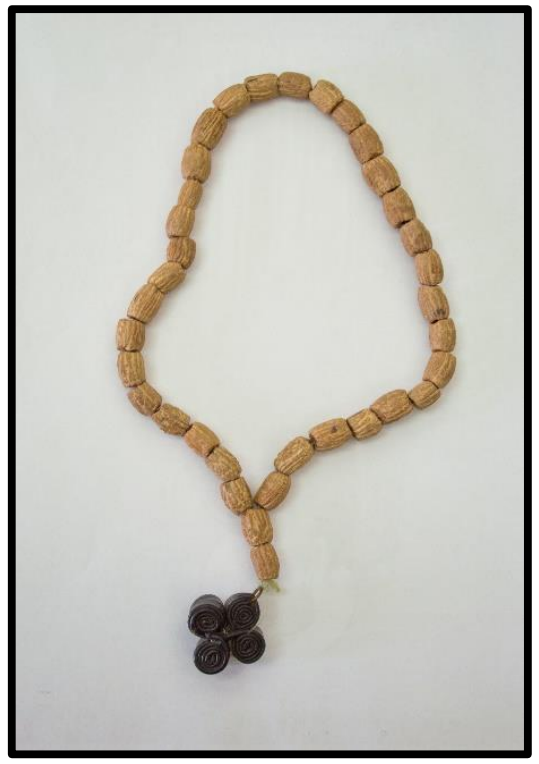

Fig.21. Examples of modern Coptic praying beads, Museum of Deir E-Surian

Monastery, Wadi El-Natrun, Egypt

Photographed by: Zeinab Hanafy 
The second example (figs. 22 a,22b) represents a praying rope of forty-one knots in black color. The rope ends with the knot takes the shape of the Greek cross.

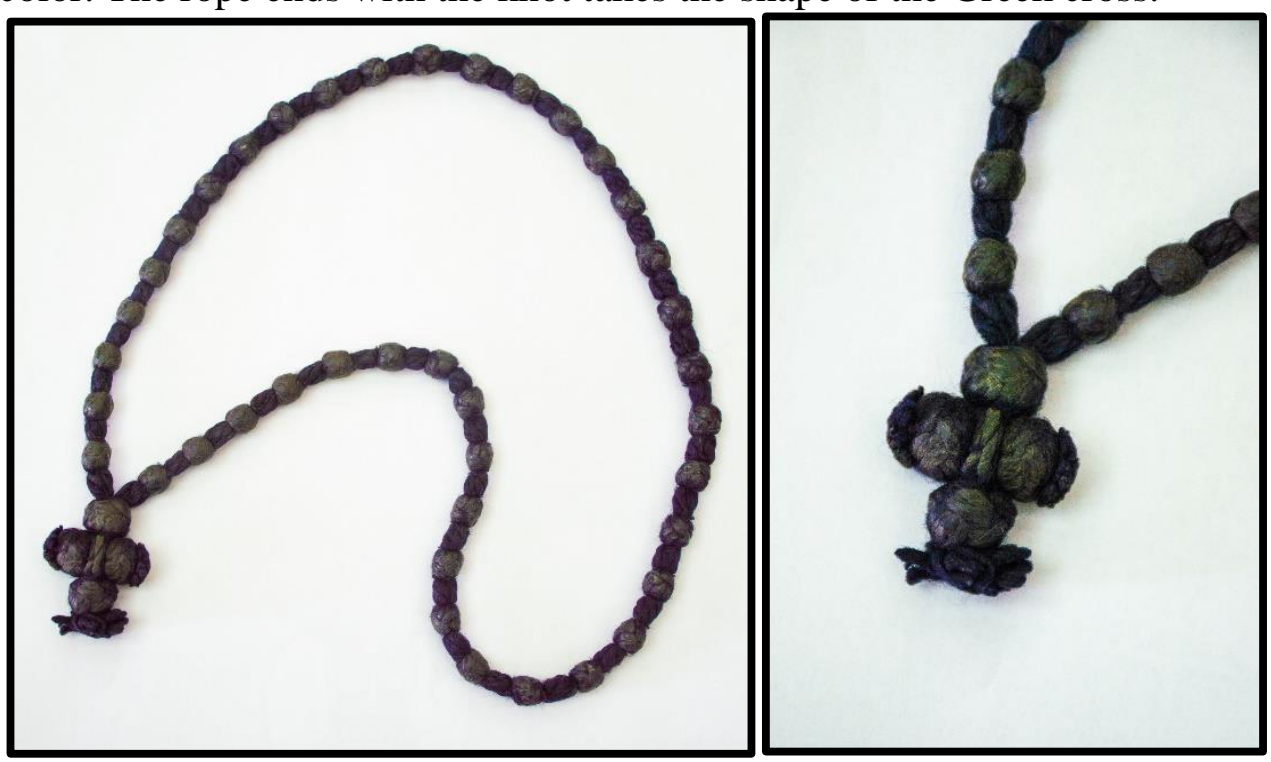

Figs. 22a, 22b. Example of modern Coptic praying rope, Museum of Deir E-Surian Monastery, Wadi El-Natrun, Egypt

Photographed by: Zeinab Hanafy

The third piece (fig.23) is the personal bead of Fr. Gregorios the Syrian. It consists of one hundred beads. Colored figures of Jesus the Christ adorn the three main terminal beads. Concerning the Latin cross, it bears the shape of the crucified Jesus in white color.

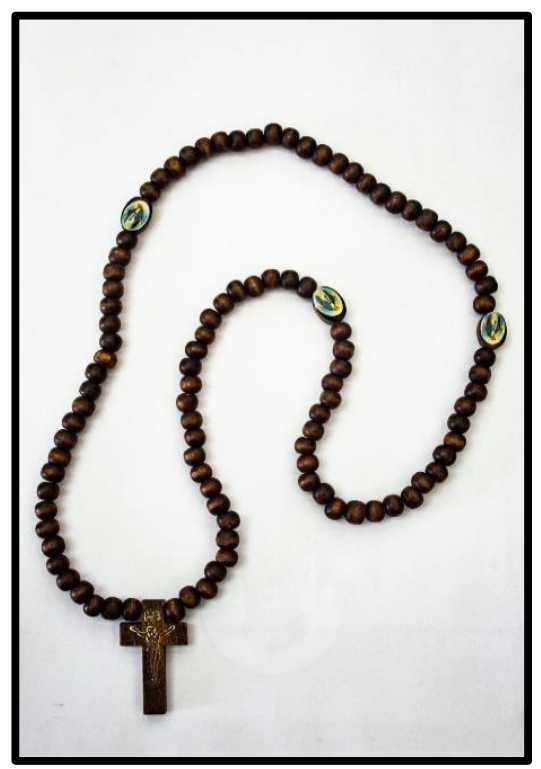

Fig. 23. the personal bead of Fr. Gregorios the Syrian, Deir El Surian Monastery, Wadi El-Natrun

Photographed by: Zeinab Hanafy 
Among the relics of St. Bishoy in Deir El-Surian Monastery in Wadi El Natrun, thirtythree beads of praying are preserved. The beads are creamy-colored and every three beads are terminated with a light pink bead. The chain of beads is topped with three beads and placed on the left side of the embroidery covering the relics of the saint (figs. $24 a, 24 b)$.

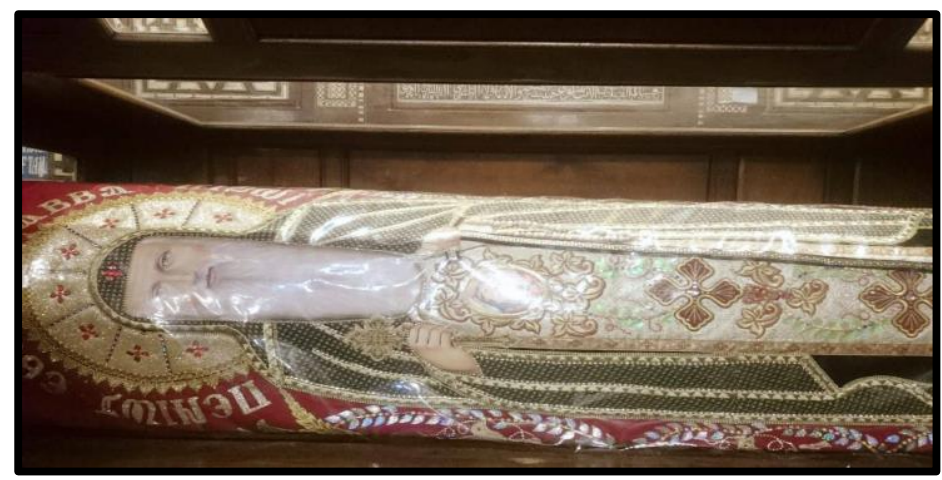

Fig.24a

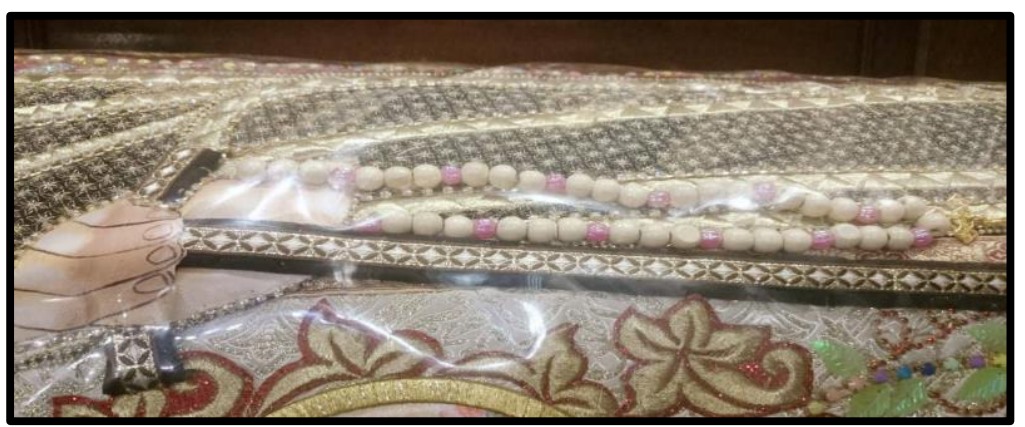

Fig.24b. colored thirty-three beads of praying placed on the left side of the embroidery covering the relics of the St. Bishoy, Deir El-Surian Monastery, Wadi El Natrun Photographed by: Zeinab Hanafy

This is another modern example of praying beads that belongs to a prominent monastic character in Egypt. ${ }^{82}$ It contains one hundred pebbles of amber topped by a terminate that ends with a cross. This cross is made of pure gold and bears the shape of the crucified Christ (fig.25).

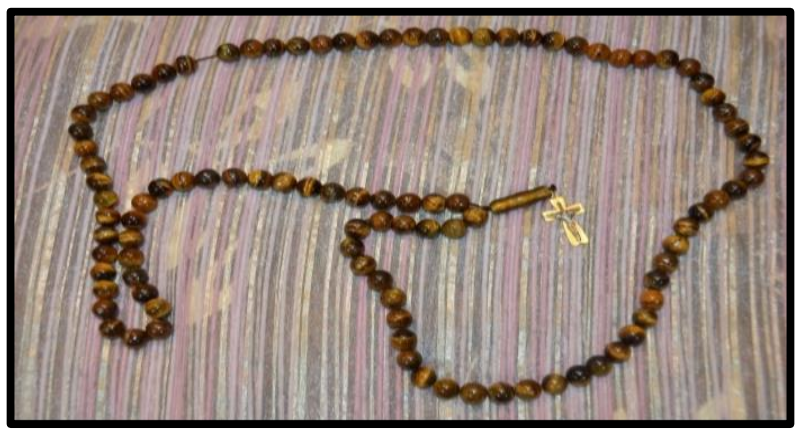

Fig. 25. Praying beads of a prominent monastic character in Egypt, beads are made of amber and the terminate is topped by a gold cross Photographed by: Zeinab Hanafy 
Using praying beads by the Copts might have inspired the Muslims in Egypt to use it to keep up counting their own holy phrases and become known by the Muslims as "subha" ${ }^{83}$ Group of scholars mention that the Rosary was introduced from Islam by the Middle Ages, as a helpful tool for those who cannot read or write to remember teachings of the Bible. ${ }^{84}$

${ }^{1}$ Blackman, Winifred S., 1918, “The Rosary in Magic and Religion”, Folklore 29, no. 4, December 30, Taylor \& Francis, Ltd, 276.

${ }^{2}$ Blackman, "The Rosary in Magic and Religion," 256.

${ }^{3}$ Today Muslims, Christians, Hindus, Buddhists use different types of praying beads that assist them performing their religious recitation; Godwin, Biin, "The Prayer Beads and Its Effect on Mental Health," 1-10 https://www.academia.edu/18970611/Prayer_Beads_and_Mental_Health; Blackman, "The Rosary in Magic and Religion," 256-280; Bell, James S, et al. The Bible Study and Prayer Book: Guidance and Insight for understanding the Bible and growing Closer to God. East Bridgewater: World Publications Group, 2011, 392; Gaster, M, " Beads and Knots," Folklore 25, no.2, Jun. 30, 1914, Taylor \& Francis, Ltd., 255; Wiley, Eleanor, and Shanon, Maggie O., A String and a Prayer: How to Make and Use Prayer Beads. Boston: Red Wheel/Weiser, 2002, 3-10. For further information concerning the usage of praying beads by the Jews see: Blackman, "The Rosary in Magic and Religion," 279-280.

${ }^{4}$ Hinnebusch, William. A. "Rosary", New Catholic Encyclopedia, 2nd ed., vol. 12. Washington, DC: Catholic University of America, 2003, 373; Walsh, Christopher, "Rosary", in Bradshaw, Paul F.,(ed.) New SCM Dictionary of Liturgy and Worship. London: SCM Press, 2005, 412. For further information about the history of using the rosary in different countries see : Herbert, Thurston, and Bruce, Eric H. S., "The History of The Rosary in all countries," The Journal of the Society of Arts, vol. 50, no. 2570 (February 21, 1902), 261-288 http://www.jstor.org/stable/41335623?seq=1\#page_scan_tab_contents

${ }^{5}$ Doerr, Nan Lewis, and Owens, Virginia Stem, Praying with Beads: Daily Prayers for the Christian Year. Michigan-Cambridge: William B. Eermans Publishing Company, 2007, viii; Solheim, Nathan, 'Meditation-more than just 'om'," Momentum: The Magazine of the National Multiple Sclerosis Society, December 22, Winter 2012-2013, 38-40; using prayer beads is based on repetition by nature, and therefore they can can help people who are seeking for of meditation. Having an obvious positive effect on the mental health, prayer beads are support healing psychological disorder known as OCD; Godwin, "The Prayer Beads and Its Effect on Mental Health," 1-10.

${ }^{6}$ Abercrombie, Sharon, A Report about the Creatively evolving Edge of Earth Spirituality, Earth Llight Magazine, 46, (2002), www.earthlight.org/2002/essay46 abercrombie pff.htm; Godwin, "The Prayer Beads and Its Effect on Mental Health," 2, 4; Walsh, "Rosary", 412-413.

${ }^{7}$ Volz, John, "Use of Beads at Prayers," In The Catholic Encyclopedia, New York: Robert Appleton Company, 1907, Retrieved April 1, 2019 from New Advent: http://www.newadvent.org/cathen/02361c.htm; Hinnebusch, "Rosary," 375. Godwin, "The Prayer Beads and Its Effect on Mental Health," 4; Blackman, "The Rosary in Magic and Religion," 274-275.

${ }^{8}$ Hinnebusch, "Rosary," 373; Walsh, "Rosary," 412-413; Bell, et al. The Bible Study and Prayer Book, 394; Finley, Mitch, Rosary Handbook, The: A Guide for Newcomers, Oldrimers, and those in Between, Frederick: The Word Among Us Press, 2017, 20-27; Ferguson, George W., Signs and Symbols in Christian Art: with Illustrations from the Paintings of the Renaissance. Oxford-New York-London: Oxford University Press, 1961, 166-169; Wolfang, 
Beinert, "Rosary," edited by Fahlbusch, Erwin, et al., The Encyclopedia of Christianity, vol. 4. Brill: William B. Eerdmans Publishing Company, 2005, 756-757.

9 Volz, "Use of Beads at Prayers; Godwin,"; Godwin, "The Prayer Beads and Its Effect on Mental Health," 5.

${ }^{10}$ Godwin, "The Prayer Beads and Its Effect on Mental Health,"4-5; Walsh, "Rosary", 412-413; Bell, et al. The Bible Study and Prayer Book, 394; Finley, Rosary Handbook, 20-25; Ferguson, Signs and Symbols in Christian Art, 166-169; Wolfang, "Rosary," 756-757.

${ }^{11}$ Hinnebusch, "Rosary," 375; Blackman, "The Rosary in Magic and Religion," 275-276; Gaster, "Beads and Knots," 255.

${ }^{12}$ Hinnebusch, "Rosary," 375; Blackman, "The Rosary in Magic and Religion," 275-276; Doerr and Owens, Praying with Beads, viii-xi.

${ }^{13}$ Hinnebusch, "Rosary," 373; Walsh, "Rosary", 412-413; Bell, et al. The Bible Study and Prayer Book, 394; Finley, Rosary Handbook, 20-25; Ferguson, Signs and Symbols in Christian Art, 166-169; Wolfang, "Rosary," 756-757.

${ }^{14}$ Hinnebusch, "Rosary," 373; Blackman, "The Rosary in Magic and Religion," 274. For more information about the Catholic Rosary see: Hinnebusch, "Rosary," 373-375; Walsh, "Rosary," 412-413.

Bell, et al. The Bible Study and Prayer Book, 394; Finley, Rosary Handbook, 20-27; Ferguson, Signs and symbols in Christian Art, 166-169; Wolfang, "Rosary," 756-757.

15 Doerr and Owens, Praying with Beads, viii-ix; Although other religions and cultures used prayer beads for long before the Catholic Church officially accepted it in 1520 through the approbation of Pope Leo X. By the time of Pope Leo XIII who is known as "Pope of the Rosary", Rosary became a crucial praying method and began to be involved during reciting the Blessed Sacrament; Hinnebusch, "Rosary", 376; Thurston, Herbert, and Shipman, Andrew," The Rosary," The Catholic Encyclopedia, vol. 13. New York: Robert Appleton Company, 1912 http://www.newadvent.org/cathen/13184b.htm ; Godwin, "The Prayer Beads and Its Effect on Mental Health,"4-5.

${ }^{16}$ Blackman, "The Rosary in Magic and Religion," 274.

17 Winston, Kimberly, Bead One, Pray Too: A Guide to Making and Using Prayer Beads. Harrisburg-New York: Morehouse Publishing, 2008, 7; De Biasi, Jean-Louis, The Magical Use of Prayer Beads: Secret Meditations and Rituals for your Qabalistic, Hermetic, Wiccan, or Druid practice. Woodbury, Minnesota : Llewellyn Publications, 2016, 1-8; Doerr and Owens, Praying with Beads, viii.

${ }^{18}$ Blackman, "The Rosary in Magic and Religion," 274; Finley, Rosary Handbook, 20-27; Herbert and Bruce, "The History of The Rosary in all countries," 266

${ }^{19}$ Finley, Rosary Handbook, 20-27; Herbert and Bruce, "The History of The Rosary in all countries," 266.

${ }^{20}$ Finley, Rosary Handbook, 20-27.

${ }^{21}$ Winston, Bead One, Pray Too, 8; Blackman, "The Rosary in Magic and Religion," 279.

22 Winston, Bead One, Pray Too, 8; Blackman, "The Rosary in Magic and Religion," 279; According to Fr. Gregorios the Syrian, he stated that St. Antony derived the usage of praying beads from the pious Christians who isolated themselves in small huts in the desert to recite their prayers.

${ }^{23}$ Blackman, "The Rosary in Magic and Religion," 278.

${ }^{24}$ Blackman, "The Rosary in Magic and Religion," 278; Winston, Bead One, Pray Too, 8; Bell, et al. The Bible Study and Prayer Book, 393.

${ }^{25}$ Blackman, "The Rosary in Magic and Religion," 276-278.

${ }^{26}$ Doerr and Owens, Praying with Beads, viii. 
${ }^{27}$ Winston, Bead One, Pray Too, 8; Bell, et al. The Bible Study and Prayer Book, 393.

${ }^{28}$ Gaster, "Beads and Knots," 257.

${ }^{29}$ Winston, Bead One, Pray Too, 8; Bell, et al. The Bible Study and Prayer Book, 393; Wiley, and Shanon, A String and a Prayer, 3-10.

${ }^{30}$ Winston, Bead One, Pray Too, 8; Bell, et al. The Bible Study and Prayer Book, 393.

${ }^{31}$ Megaloskema: meaning great skeme (Arabic: el eskim) the highest degree of the monk based on his contemplative monastic attitude: Van Doorn-Harder, Pieternella, Contemporary Coptic Nuns. University of South Carolina Press, 1995, 68, 229.

${ }^{32}$ Such knots are also found in Indian temples where knots are tied into strings; Blackman, "The Rosary in Magic and Religion," 257-258; Doerr and Owens, Praying with Beads, vii-viii; Wiley, and Shanon, A String and a Prayer, 5-6.

${ }^{33}$ Blackman, "The Rosary in Magic and Religion," 257-258; Gaster, "Beads and Knots," 254258.

${ }^{34}$ Blackman, "The Rosary in Magic and Religion," 279; Doerr and Owens, Praying with Beads, vii-viii.

${ }^{35}$ Mathew 9:27, 15:22, 20:30; Mark 10:47; Luke 18:38; Archbishop Basilios, "Kyrie Elesion," Claremont Coptic Encyclopedia, CE:1420b-1421b $\quad 1$ http://ccdl.libraries.claremont.edu/cdm/ref/collection/cce/id/1183; Farag, Lois M., Balance of the Heart: Desert Spirituality for Twenty-First-Century Christians, Eugene, Oregon: Cascade Books, 2012, 140-142.

${ }^{36}$ Doerr and Owens, Praying with Beads, vii-viii; Winston, Bead One, Pray Too, 8; Eshagh, Patricia " Jesus Prayer," Claremont Coptic Encyclopedia, 1 http://ccdl.libraries.claremont.edu/cdm/ref/collection/cce/id/2141.

${ }^{37}$ Eshagh, " Jesus Prayer," 1.

${ }^{38}$ Eshagh, "Jesus Prayer," 1.

${ }^{39}$ Eshagh, "Jesus Prayer," 1; Tim, Vivian, (trans.), Saint Macarius the Spiritbearer: Coptic Texts Relating to Saint Macarius the Great. Popular Patristic Series 28. Crestwood, New York: St. Vladimir's Seminary Press, 2004, 72; Farag, Balance of the Heart, 140.

${ }^{40}$ Eshagh, "Jesus Prayer," 1; AP Macarius the Great 19; Tim, Saint Macarius the Spiritbearer, 97.

${ }^{41}$ Blackman, "The Rosary in Magic and Religion," 279.

${ }^{42}$ Winston, Bead One, Pray Too, 8.

${ }^{43}$ Among the three female figures, Marinatos assumed that the central figure is the goddess. Her opinion is based on three reasons; the shape of the central woman is larger than the other figures. Unlike the two lateral figures, the woman in the middle is depicted in the seated position. Finally, the position as well as the gesture of the two flanking females confirms the importance of the central female figures. Both of the woman on the left and the teenage at the right are directed to the seated woman in the middle and are depicted presenting gifts to her; Marinatos, Nanno, Akrotiri: Thera and the East Mediterranean, Athens: Militos 2015 121-122 https://www.academia.edu/15669267/AKROTIRI_THERA_AND_THE_EAST_MEDITERRA NEAN

${ }^{44}$ Doumas, Christos, Wall Paintings of Thera. Athens:Thera-Foundation Petros M. Nomikos, 1992, pl. 100; Marinatos, Akrotiri, 121-125

45 The blood of the Minoan goddess of Akrotiri seems to have played a crucial mythological role. This goddess was apparently goddess of fertility. The discovery of many nippled ewers might confirms this hypothesis. These jugs take the shape of the female breasts and belly reflecting the fertile nature of the goddess. Being goddess of fertility and nature, the crocus, lily, rosette, and spiral were her sacred symbols. For further detail see; Marinatos, Akrotiri, 125.

${ }^{46}$ Doumas, Wall Paintings of Thera, pl. 100; Marinatos, Akrotiri, 121-125 
${ }^{47}$ Gaster, "Beads and Knots," 254-255.

${ }^{48}$ St. Paul the Hermit or Paul of Thebes: A biography of this saint is to be found in the Greek resources of St. Jerome "Jerome's saint of Paul of Thebes". This work was that was done around 375 A.D; gives an account about St.Paul as a wealthy orphan from Thebes who escaped the persecution of emperor Decius and went to the desert of Thebes to start his monastic life. In art, St. Paul is depicted as an aged man with long white beard and a humble garment made of palm fronds and in many cases accompanied by St. Anthony. Some resources suggest his death after 345 A.D. For further details see: Roddy Kevin, "Paul the Hermit" Holy People of the World: A cross Cultural Encyclopedia, Vol. III, Santa Barbara (Calif.) : ABC-CLIO, cop. 2004,679; Leslie Ross, Medieval Art: A Topical Dictionary. Westport, Conn: Greenwood Press, $1996,149$.

${ }^{49}$ Selections from the Egyptian Heritage: Icons of the Coptic Museum. Egypt: Ministry of Culture, Cultural Development Fund, 2000, 11.

${ }^{50}$ Van Moorsel, Paul, The Icons; catalogue general du musée copte. Cairo: Supreme Council of Antiquities and Leiden University: Department of Early Christian Art, 1991, 28, pl. 7c

${ }^{51}$ Church of St. Shenute: is one of the most ancient churches of Old Cairo situated in the Babylon fortress. The church was firstly mentioned in the writings as early as the eight century $\mathrm{AD}$. In $743 \mathrm{AD}$, an assembly of clergy and bishops gathered in this church during electing the new Patriarch. The church was renovated in 1327- 1339 AD; Meindarus, Two Thousand Years of Coptic Christianity, 189-190.

${ }^{57}$ St. Anthony the Great: He was born in 251 A.D at Koma, in Upper Egypt, Despite being a son for a wealthy Christian family, he showed no interest in learning any foreign language rather than his native Coptic or Egyptian. During his early life he became an orphan and the sole guardian of his only sister. In 268 while Anthony was attending a lesson in the church he listened to the verse "If you want to be perfect, go, sell your possessions and give to the poor, and you will have treasure in heaven. Then come, follow me." (Mat.19:22). He felt this verse was a personal sign form him and he decided to sell all of his processions and distribute the money among the needy, then he went off to the desert to start his solitary monastic life. When he was about 34 years old, he settled himself in an old castle by the Nile River. In the course of time, his existence became known to the locals who sought his teachings and built their own houses around him. The saint as well in return accepted them as his pupils. The saint died by the year 365 A.D. For more detail see: Morgan Robert, History of the Coptic Orthodox People and the Church of Egypt. Victoria, Canada : Friesen Press, 2016,43-46; Rubenson Samuel, The Letters of St. Antony: Monasticism and the Making of a Saint. Minneapolis Fortress Press 1997.

${ }^{53}$ Attalah, Nabil Selim, Les Icônes Coptes; Kotische Ikonen, Cairo, Lehnert \& Landrock, 1986, 122,123

${ }^{54}$ Attalah, Coptic Icons, Les Icônes Coptes, 24, 25; The Church of Saints Cyrus and John; is one of the churches of Babylon fortress. It is a small church with a simple square design. It consists of a nave, a choir, two sanctuaries as well as a polygonal baptistery made of masonry. The southern sanctuary is consecrated for St.George. Concerning the norther one, it is dedicated to St. Cyrus and St. John; Meindarus, Two Thousand Years of Coptic Christianity, 183, 186.

${ }^{55}$ Van Moorsel, The Icons, 63, pl. 16a.

${ }^{56}$ Van Moorsel, The Icons, 64, pl. G2.

${ }^{60}$ Sts. Abraham and George of the Scetis: They are two saints from the seventh century who shared the same cell for years. These two saints among others brought great notability to the monastery of St. Macarius. In respect of art, the two saints are always represented together. Zacharias, the bishop of Sakha wrote them a joint biography. St. Abraham was born around 608 
A.D, after the death of his father he refused to get married and set off to the Scetis at the age of thirty-five where he started his monastic life in the monastery of St. Macarius. St. George's place of birth is unidentified. He started his life as a shepherded and at the age of fourteen he set off to the monastery of Anba Orion where he became a monk and met St. George. The two saints are called "the great saints" as it seems they were the last two to live the hermitage life away from the ecclesiastical hierarchy. For further detail see: René-Georges Coquin, "Saints Abraham and George of Scetis", Claremont Coptic Encyclopedia: 12a-13a http://ccdl.libraries.claremont.edu/cdm/singleitem/collection/cce/id/27/rec/1; Hugh Gerard Evelyn-White, Walter Hanser, The Monasteries of the Wadi'n Natrun. New York: Arno Press, 1973, 279.

${ }^{58}$ Van Moorsel, The Icons, 66, pl. 6c.

${ }^{59}$ Markus al-Antuni (1295/6-1386 AD): is one of the prominent saints in the Monastery of St. Antony. He started his life as a monk at the age of twenty-three. His monastic trainee was attested in the Monastery of St. Paul where he spent six years. The biography of this saint, including his thirty-four wonders, is documented in manuscripts preserved in the library of the Monastery of St. Paul. Marqus dug his own tomb in the garden of the monastery where he isolated himself for fasting. Because of his abstinent fasting practice, the monks sent the saint back again to the Monastery of St. Antony. Markus al-Antuni became the spiritual father for common people, monks as well as priests. His character obviously inspired his followers including priest Matta who became later Patriarch Mathew I (1378-1408 AD); Swanson, Mark N. "The Monastery of St. Paul in Historical Context," in Lyster, William (ed.), The Cave Church of Paul the Hermit at the Monastery of St. Paul, Egypt. New Haven: Yale University Press, 2008, 49-50.

${ }^{60}$ Swanson, "The Monastery of St. Paul in Historical Context," 50-51, fig.2.4

${ }^{66}$ St. Pachomius: He is known for being the founder of the cenobitic monasticism. The saint was born of pagan parents in Upper Egypt and became a solider in the Roman army. After he was released from the army, he went to a village called Sheneset where he was baptized. Afterwards he became a disciple of Palamon who was a hermit too. Saint Pachomius decided to abandoned himself in another village called Tabennese he established his system in monasticism. For more detail see: Armand Veilleux, "Saint Pachomius", Claremont Coptic Encyclopedia, CE: 1859a-1864b, http://ccdl.libraries.claremont.edu/cdm/singleitem/collection/cce/id/1497/rec/1

${ }^{62}$ Attalah, Coptic Icons, Les Icônes Coptes, 78, 79.

${ }^{68}$ Other examples could be witnessed in other sites; an icon representing St. Matthew the potter accompanied by three other peasants' martyrs. The icon is of Ansatasi Al-Rumi during the 19th century. See Attalah, Coptic Icons,Les Icônes Coptes, 94. Another icon of St. Sajnt Hor at Dair Sawada, Minieh. Also an icon of St. John colobus of sects preserved in the monastery of St. Maccarius in wadi Al-Natrun. The two icons are of the works of Ansatasi Al-Rumi during the 19th century, see; Attalah, Coptic Icons, 96.

${ }^{64}$ Monastery of St. Bishoi (Deir Anba Bishai): this monastery is dedicated to St. Bishoi who went to the desert in Scetis and met St. John the Short. After living with the company of St. Bishoi, St. John who isolated himself in the desert for a long time, enhanced St. Bishoi to live alone in a cave in the desert. After the Barbers' attack in $407 \mathrm{AD}$, the two saints escaped. St. Bishoi settled in a mountain in El-Fayoum where he met St. Paul of Tammua. Concerning St. John the Short, he found refuge in the monastery of St. Antony. The most ancient part of this monastery dates back to the seventh century AD; Meindaurus, Two Thousand Years of Coptic Christianity, 164-164.

${ }^{65}$ Attalah, Coptic Icons, Les Icônes Coptes, 94, 95 
${ }^{66}$ Attalah, Coptic Icons, Les Icônes Coptes, , 100, 101; Dair El-Baramus: is one of the earliest establishments in Wadi El-Natrun. The name of this monastery is an Arabic modification of the Coptic Phrase "Pa-Romeos" meaning "of the Romans". Its establishment was clearly connected to the Roman Sts. Maximus and Domitius, sons of the Roman emperor Valentinian. According to tradition, the two saints visited the Christian shrines of Nicaea and Palestine and ended their journey in Wadi El-Natrun. In this site, they met St. $t$ Macarius and decided to build their own cell in the desert. After their death, St. Macarius dedicated this cell to them and was called Cell of the Romans. It is believed that the relics of the two saints is preserved beneath the central altar of $\mathrm{Al} \mathrm{Adrha} \mathrm{church} \mathrm{in} \mathrm{this} \mathrm{monastery.} \mathrm{Monastic} \mathrm{community} \mathrm{appeared} \mathrm{around} \mathrm{this} \mathrm{cell} \mathrm{as}$ early as the fourth century AD. This monastery, which became known as the Holy Virgin of al Baramus, produced many theologians during the Middle Ages. Two monks of this monastery became patriarchs in the seventeenth century AD; namely Mathew III (1631-1646 AD) and Mathew IV (1660-1675 AD). For further detail see; Meindarus, Two Thousand Years of Coptic Christianity, 157-158.

${ }^{70}$ Abib (or Apip) and Apollo: They were two colleagues who choose to become monks. Abib had the deaconate rank and was martyred. Apollo was distressed and decided to move deeper into the desert. He was also martyred. For more detail see: Atiya Aziz S., "Coptic Martyrs", Claremont Coptic Encyclopedia, 1550b-1559b, http://ccdl.libraries.claremont.edu/cdm/singleitem/collection/cce/id/1330/rec/1;

${ }^{68}$ Attalah, Coptic Icons, Les Icônes Coptes, 98, 99.

${ }^{69}$ Attalah, Coptic Art, 112-113.

${ }^{74}$ A similar example is preserved in the Coptic church of St. Mary, Haret Al'Rum, Cairo of St. Shenouda and his disciple Anba Wissa where St. Shenouda is holding black praying beads with his right hand along with a Latin cross. For more detail see; Attalah, Coptic Icons, 60.

${ }^{71}$ Zibawi, Mahmoud, Images de l'Egypte chrétienne: iconologie copte, Paris: Picard; Milano : Jaca Book, 2003, 215, fig. 290.

${ }^{72}$ Attalah, Coptic Icons, Les Icônes Coptes, 32; St. Pachomius: was the founder of the Christian communal life and the founder of the first coenobium in Upper Egypt. St. Pachomius was also the first abbot of a dual monastery that comprises monks and nuns together. Meindarus, Two Thousand Years of Coptic Christianity, 1-2, 130.

${ }^{73}$ Attalah, Coptic Icons, Les Icônes Coptes, 32.

${ }^{74}$ Attalah, Coptic Icons, Les Icônes Coptes, 28, 29; The three Macarii; The first one refers to St. Macarius the Great whose relics were sent to Wadi El Natrun during patriarch John IV (777-99). In addition, monasteries of Wadi El-Natrun contains relics of the St. Macarius of Alexandria. The same reliquary contains the relics of St. Macarius of Tkow. The relics of the three macarii is preserved in the reliquary of the Church of St. Macarius in his monastery in Wadi El-Natrun; Meindarus, Two Thousand Years of Coptic Christianity, 317-318.

79 Attalah, Coptic Icons, 48.

${ }^{78}$ Another similar example could be witnessed in an icon preserved in monastery of St. Paul, the Eastern Desert, the Red Sea. It represents Holy Virgin Mary standing between St. Paul and St. Anthony holding praying beads and at the top two flying angels are depicted holding swords. For further detail see: Attalah, Coptic Icons, 23.

${ }^{77}$ Attalah, Coptic Icons, 60

${ }^{78}$ Skalova, Zuzana, and Gabra, Gawdat, Icons of the Nile Valley. Cairo: Egyptian International Publishing-Longman, 2006, 120.

${ }^{79}$ Tangible Heritage: is defined to be something that could be permanently viewed and touched including the immovable, movable objects and underwater cultural heritage. This type of heritage helps in understanding the human history. The immovable objects are represented in 
historical sites, architectural sites, monuments or buildings. Concerning the movable objects, they include artifacts, archaeological objects, architecture objects, science objects, and technology objects. Hamilton, Fiona, "Tangible and Intangible Cultural Heritage, " 1 http://designonline.org.au/wp-content/uploads/2018/05/Cultural-Heritage.pdf .

${ }^{80}$ According to the definition of UNESCO, Intangible Cultural Heritage (ICH) involves practices, representations, knowledge and skills as well as the instruments, objects, artifacts and cultural space of a certain community. This intangible cultural heritage is continuously recreated by communities and groups in response to their environment, their interaction with nature and their history. This cultural context reflects the identity of the society and is transmitted from generation to generation. Facing the growing globalization, the global community is regarded being the best representative of the ICH maintaining its sustainability; UNESCO, Convention for the Safeguarding of the Intangible Cultural Heritage, MISC/2003/CLT/CH/14 § (2003), para 2.1. Retrieved from http://unesdoc.unesco.org/images//0013/001325/132540e.pdf; UNESCO, What is Intangible?, 4-5 https://ich.unesco.org/doc/src/01851-EN.pdf; Amer, Mohamed B., Egyptian Intangible Heritage between Preservation Management and Sustainable Development Pattern: Analysis of the Popular $\begin{array}{lllll}\text { Craft } \text { Manufacturing } & \text { Cairo, } & 2007, & 4\end{array}$ https://www.academia.edu/30650865/Egyptian_Intangible_Heritage_between_Preservation_Manag ement and Sustainable Development Pattern Analysis of the Popular Craft of Manufacturing Mats;

${ }^{81}$ We owe our gratitude to Fr. Gregorios the Syrian in the Monastery of Deir El-Surian in Wadi El-Natrun for the valuable information he presented concerning praying beads and their usage in modern Christian life.

${ }^{82}$ Under his own request, the name of the owner is not mentioned in the research.

${ }^{83}$ The praying beads of the Muslims is made up of either thirty-three pebbles or ninety-nine pebbles divided to three groups through small disks. The "subha" helps Muslims to keep counting their recitations and is used by the common worshippers. Muslims use to recite the following phrases and count them on their subha; Subhannallah (Glory to Allah) - 33 times; Alhamdilillah (Praise be to Allah) - 33 times; Allahu Akbar (Allah is Great) - 33 times. Such recitations will cause the forgiveness of the one's sins; Godwin, "The Prayer Beads and Its Effect on Mental Health,"3-4; Blackman, "The Rosary in Magic and Religion," 258, 270-274; Dubin, Lois Sherr "The World of Islam," in Dubin, Lois Sherr (ed.), The History of Beads: From 100,000 B.C. to the Present (Revised and Expanded Edition). New York: Abrams Publishing, 2009, 93-100.

${ }^{84}$ For more information about the Catholic Rosary see: Walsh, "Rosary", 412-413; Bell, et al. The Bible Study and Prayer Book, 394. Finley, Rosary Handbook, 20-27; Ferguson, Signs and symbols in Christian Art, 166-169; Wolfang, "Rosary," 756-757. 


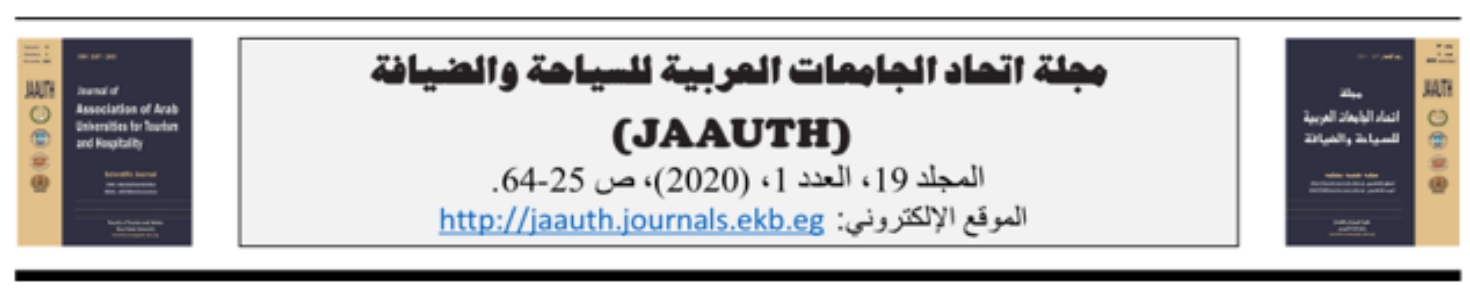

العبحة وأحبال الصلاة في الفن القبطي في سياق التراث القبطي

$$
\text { زينب حصن }
$$

باحث مساعد بمركز الدراسات القبطية

بمكتبة الأسكندرية الناية

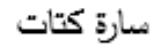

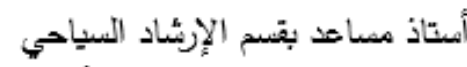

كلية السياحة والفنادق، جامعة الأسكندرية

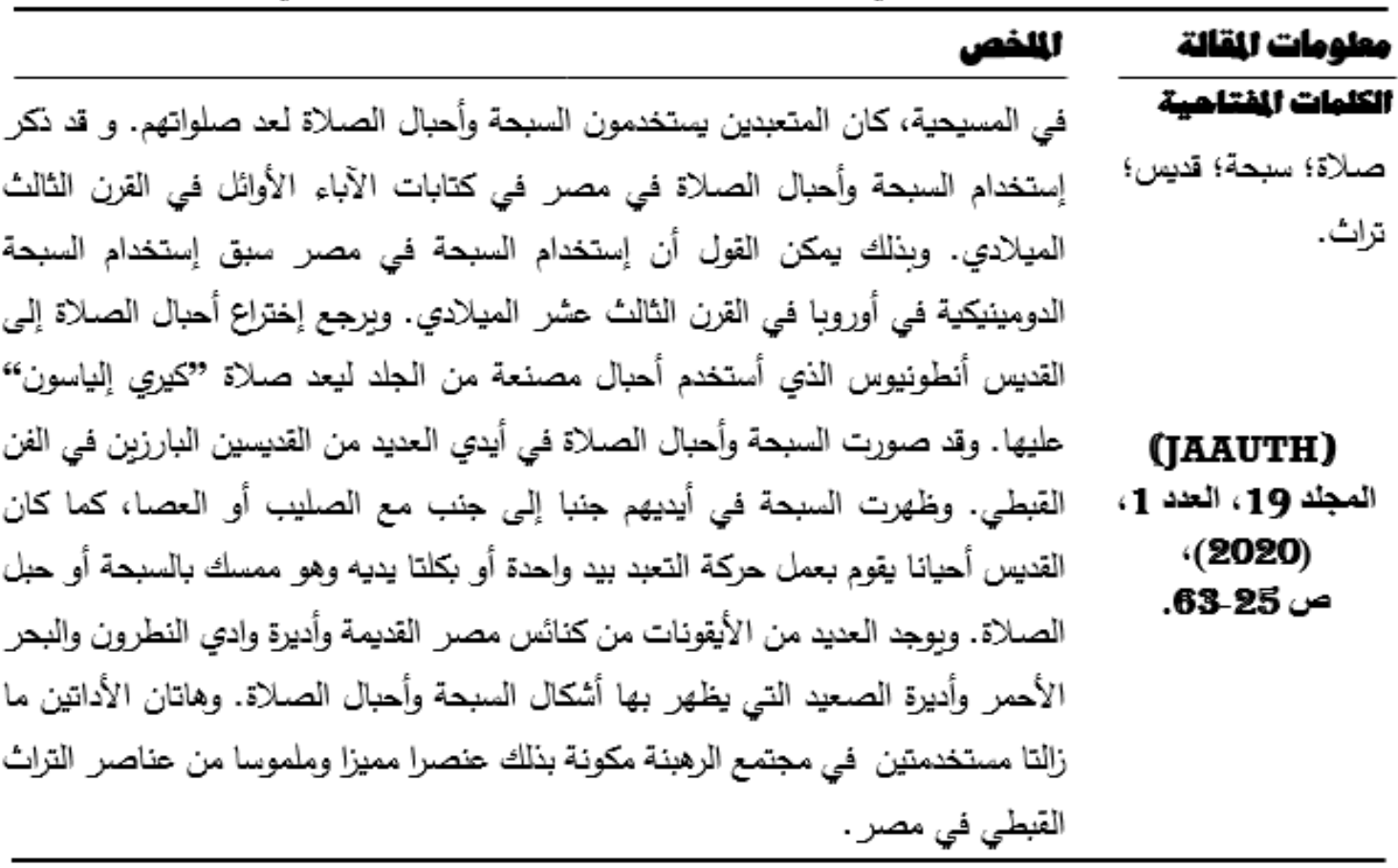

